\title{
Disturbance and the resilience of coupled carbon and nitrogen cycling in a north temperate forest
}

\author{
L. E. Nave, ${ }^{1}$ C. M. Gough, ${ }^{2}$ K. D. Maurer, ${ }^{3}$ G. Bohrer, ${ }^{3}$ B. S. Hardiman, ${ }^{4}$ J. Le Moine,,${ }^{1,5}$
} A. B. Munoz, ${ }^{6}$ K. J. Nadelhoffer, ${ }^{1,5}$ J. P. Sparks, ${ }^{7}$ B. D. Strahm, ${ }^{8}$ C. S. Vogel, ${ }^{1}$ and P. S. Curtis ${ }^{4}$

Received 11 May 2011; revised 9 August 2011; accepted 17 August 2011; published 29 October 2011.

[1] Much of our biogeochemical understanding of forest disturbances comes from studies of severe or stand-replacing events, which may have different impacts on coupled carbon (C) and nitrogen $(\mathrm{N})$ cycling than subtler disturbances affecting only a fraction of the canopy. We measured a suite of interdependent $\mathrm{C}$ and $\mathrm{N}$ cycling processes following an experimental disturbance that accelerated mortality of the early successional canopy dominants (39\% of basal area) in an aging secondary forest, hypothesizing that this subtle, spatially diffuse disturbance would temporarily decouple $\mathrm{C}$ and $\mathrm{N}$ cycles by decreasing belowground $\mathrm{C}$ allocation and thereby alter $\mathrm{N}$ cycling rates and pathways. We postulated that a short-term decrease in ecosystem $\mathrm{C}$ uptake and an increase in $\mathrm{N}$ leaching would accompany this decoupling, but that concomitant increases in $\mathrm{N}$ availability and uptake by later successional species would promote rapid resilience of coupled $\mathrm{C}-\mathrm{N}$ cycles along new, stable trajectories. Disturbance decreased belowground C allocation and soil respiration, accelerated root turnover, and decreased root mass. These perturbations increased forest floor $\mathrm{NH}_{4}^{+}$and $\mathrm{NO}_{3}^{-}$availability and $\mathrm{NO}$ emission, and declining root function caused water stress and $\mathrm{N}$ deficiency in senescent trees. Foliar $\mathrm{N}$ and leaf area increased in later successional trees, suggesting that enhanced $\mathrm{N}$ uptake supported new leaf area production. Two years after disturbance, $\mathrm{N}$ leaching losses and the decline in net ecosystem $\mathrm{CO}_{2}$ exchange were small, suggesting that coupled $\mathrm{C}-\mathrm{N}$ cycling was resilient to this subtle experimental disturbance. Therefore, compared with the severe disturbances reported in the literature, our subtle disturbance likely will have different effects on longer-term forest biogeochemical trajectories.

Citation: Nave, L. E., et al. (2011), Disturbance and the resilience of coupled carbon and nitrogen cycling in a north temperate forest, J. Geophys. Res., 116, G04016, doi:10.1029/2011JG001758.

\section{Introduction}

[2] The world's forests are subject to disturbances now occurring at a rate and spatial extent without precedent in recorded history and rivaled in recent geologic time only by Pleistocene glaciations [Davis, 1989; Overpeck et al., 1990;

\footnotetext{
${ }^{1}$ University of Michigan Biological Station, Pellston, Michigan, USA.

${ }^{2}$ Department of Biology, Virginia Commonwealth University, Richmond, Virginia, USA.

${ }^{3}$ Department of Civil and Environmental Engineering and Geodetic Science, Ohio State University, Columbus, Ohio, USA.

${ }^{4}$ Department of Evolution, Ecology, and Organismal Biology, Ohio State University, Columbus, Ohio, USA.

${ }^{5}$ Also at University of Michigan, Department of Ecology and Evolutionary Biology, Ann Arbor, Michigan, USA.

${ }^{6}$ Columbia University, New York, New York, USA.

${ }^{7}$ Department of Ecology and Evolutionary Biology, Cornell University, Ithaca, New York, USA.

${ }^{8}$ Department of Forest Resources and Environmental Conservation, Virginia Polytechnic Institute and State University, Blacksburg, Virginia, USA.

Copyright 2011 by the American Geophysical Union. 0148-0227/11/2011JG001758
}

Webb and Bartlein, 1992]. However, while global disturbance frequency is on the rise, disturbance intensity is changing in many forested regions of the world. For example, in the Great Lakes region of North America, forest disturbances are transitioning away from severe events that historically caused complete stand replacement toward more subtle disturbances that cause only partial canopy defoliation or the loss of selected species [Pregitzer and Euskirchen, 2004; Birdsey et al., 2006; Luyssaert et al., 2008]. The principal cause of this change is a shift from widespread clear-cut harvesting and fire in primary forests in the late 19th to early 20th centuries to subtler anthropogenic and natural disturbances in recent decades that affect only one or a few tree species in each secondary forest community. These subtler disturbances include partial harvests, pathogenic insects, diseases, and age-related senescence [Kinney et al., 1997; Caspersen et al., 2000; Knohl et al., 2002; Birdsey et al., 2006; Lindroth et al., 2009]. The lattermost of these disturbances has become particularly common in older secondary forests of the Great Lakes region, where early successional (often clonal) canopy species are dying and giving way to later successional 


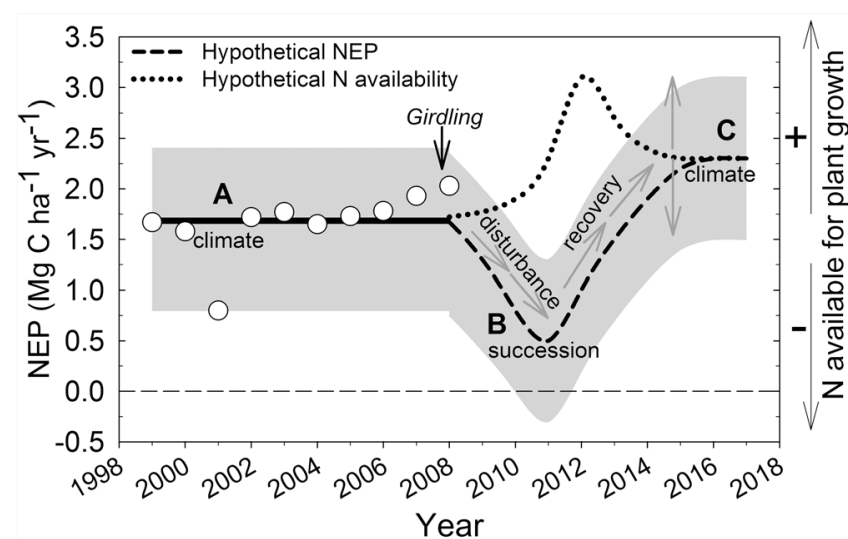

Figure 1. Measured and hypothetical NEP and N availability at UMBS before and following aspen and birch decline. Points are A, current NEP varies interannually because of climate, $\mathrm{B}$, a period constrained by disturbance and recovery follows aspen and birch mortality, and $\mathrm{C}$, short-term increases in $\mathrm{N}$ availability and allocation to the canopy persist into successional time, allowing diversification of canopy structure and an increase in average annual NEP, which is once again constrained by climate.

canopy dominants [Palik and Pregitzer, 1993; Frelich and Reich, 1995; Kneeshaw and Bergeron, 1998; Stearns and Likens, 2002; Wolter and White, 2002; Hill et al., 2005]. The rise of these subtler disturbances may have important consequences for coupled forest $\mathrm{C}$ and $\mathrm{N}$ cycling, but these consequences cannot be predicted from our current understanding, which is largely derived from studies of severe, stand-replacing disturbances and single-element dynamics in recently disturbed forests.

[3] Biogeochemical cycles of carbon $(\mathrm{C})$ and nitrogen $(\mathrm{N})$ are linked by multiple-component processes, but disturbances may decouple these cycles [Asner et al., 1997; Boerner et al., 2008; Vitousek and Howarth, 1991]. During a century of relatively low-disturbance regrowth, forests of the Great Lakes region have maintained $\mathrm{C}$ uptake rates that are generally constrained by $\mathrm{N}$ availability [Nadelhoffer et al., 1985; Nave et al., 2009; Zak et al., 1989], but future coupling of $\mathrm{C}$ and $\mathrm{N}$ cycles may be temporarily disrupted as senescing early successional trees become net sources of, rather than sinks for, these elements. Studies of severe disturbances suggest that these events can rapidly decouple $\mathrm{C}$ and $\mathrm{N}$ cycles, decreasing forest production and consequently increasing N losses [Bormann and Likens, 1979; Foster et al., 1997; Sprugel, 1984]. These results may or may not apply to $\mathrm{C}$ and $\mathrm{N}$ cycling following subtler disturbances in which only a fraction of trees die, but this remains poorly known because few studies have examined coupled, ecosystem-scale $\mathrm{C}$ and $\mathrm{N}$ cycling after subtle disturbances [Kaye et al., 2005; Reich et al., 2001]. Because disturbances can create long-term biogeochemical legacies [Goodale and Aber, 2001; Gough et al., 2007], quantifying disruptions in $\mathrm{C}$ and $\mathrm{N}$ cycling processes immediately following subtle disturbances may help elucidate how initial forest responses to disturbance drive longer-term trajectories of $\mathrm{C}$ storage and $\mathrm{N}$ availability.

[4] To determine the mechanisms by which coupled $\mathrm{C}$ and $\mathrm{N}$ cycles respond to the subtle disturbance of partial canopy mortality, and to test whether early responses initiate biogeochemical trajectories that are stable over longer time scales, we initiated a large-scale manipulation at the University of Michigan Biological Station (UMBS). The Forest Accelerated Succession Experiment (FASET), in which we stem girdled $>6700$ early successional aspen (Populus spp.) and birch (Betula papyrifera) trees (comprising 39\% of basal area) in 2008 within a 39 ha area, is testing the overarching, long-term hypothesis that annual net $\mathrm{C}$ storage, defined as net ecosystem production (NEP), will increase as the canopy becomes more biologically and structurally complex. In this paper, we test the short-term hypothesis that a subtle disturbance will decouple $\mathrm{C}$ and $\mathrm{N}$ cycles by decreasing belowground $\mathrm{C}$ allocation, increasing soil $\mathrm{N}$ availability and leaching, but that this decoupling will be temporary because of a mechanism for functional resilience: a rapid increase in $\mathrm{N}$ uptake and compensating growth by the residual canopy. We link our short- and long-term hypotheses by predicting that recoupling of $\mathrm{C}$ and $\mathrm{N}$ cycles along a new trajectory following the loss of early successional species will interact with changes in canopy structure to determine the eventual direction and magnitude of NEP recovery (Figure 1). In assessing the broader impacts of our study, we discuss likely implications of similar disturbances on coupled $\mathrm{C}$ and $\mathrm{N}$ cycling, and on future NEP, in temperate forests with similar disturbance histories.

\section{Materials and Methods}

\subsection{Study Site and Experimental Design}

[5] We conducted this study at the University of Michigan Biological Station (UMBS), in northern Michigan $\left(45^{\circ} 35^{\prime} \mathrm{N}\right.$, $\left.84^{\circ} 43^{\prime} \mathrm{W}\right)$, where the mean annual temperature is $5.5^{\circ} \mathrm{C}$ (1942-2003) and mean annual precipitation is $817 \mathrm{~mm}$ (including $294 \mathrm{~cm}$ snowfall). The study area encompasses $\sim 140$ ha on a high outwash plain and adjacent gently sloping moraine. Nearly all soils in the study area are well to excessively well drained Haplorthods of the Rubicon, Blue Lake, or Cheboygan series. Soils throughout the study area have forest floors consisting of Oe horizons $1-3 \mathrm{~cm}$ thick overlying bioturbated AO horizons of $1-3 \mathrm{~cm}$ held together by dense fine roots. The remainder of the soil profile within the predominant rooting zone includes an $\mathrm{E}$ horizon of 10 $15 \mathrm{~cm}$ and a Bs horizon of sand with occasional gravel and cobble. About 53\% of the fine-root mass is located within the upper $20 \mathrm{~cm}$ of the soil profile. Forest floor $\mathrm{C}$ mass is 5$15 \mathrm{Mg} \mathrm{C} \mathrm{ha}{ }^{-1}$, and the mineral soil is $\sim 95 \%$ sand and $\sim 5 \%$ silt, with $\mathrm{pH} 4.5-5.5$ in water. Soils are of low fertility, with total $\mathrm{N}$ capital to $40 \mathrm{~cm}$ depth of $2000 \mathrm{~kg} \mathrm{ha}^{-1}$, an average in situ net $\mathrm{N}$-mineralization rate of $42 \mathrm{~kg} \mathrm{~N} \mathrm{ha}^{-1} \mathrm{yr}^{-1}$ and $<2 \%$ net nitrification [Nave et al., 2009].

[6] The forest structure within the study area is described in Table 1. Bigtooth aspens (Populus grandidentata), although already undergoing age-related decline in some stands at the time of stem girdling, dominate the canopy of the secondary successional forest within the study area [Gough et al., 2010]. Other canopy species include red maple (Acer rubrum), red oak (Quercus rubra), white birch (Betula papyrifera), eastern white pine (Pinus strobus), trembling aspen (Populus tremuloides), sugar maple (Acer saccharum), and American beech (Fagus grandifolia). Forest composition and disturbance history at the study site are representative of forests across the northern Great Lakes region, where aspen- and 
Table 1. Structure and Age of the Study Forest at the University of Michigan Biological Station

\begin{tabular}{lcc}
\hline \multicolumn{1}{c}{ Parameter } & Value & Units \\
\hline Tree density $^{\mathrm{a}}$ & 750 & $\mathrm{stems} \mathrm{ha}^{-1}$ \\
Basal area & 25 & $\mathrm{~m}^{2} \mathrm{ha}^{-1}$ \\
Leaf Area Index & 3.5 & $\mathrm{~m}^{2} \mathrm{~m}^{-2}$ \\
Canopy height & 22 & $\mathrm{~m}$ \\
Maximum stand age & 90 & $\mathrm{yr}$ \\
\hline
\end{tabular}

${ }^{\mathrm{a}}$ Trees $\geq 8 \mathrm{~cm}$ diameter at breast height.

birch-dominated hardwoods replaced pine-hemlock (Tsuga canadensis) forests following clear-cutting and wildfires that ended in the early 20th century [Gough et al., 2007]. Stem girdling of the early successional species was a 3 week process in April-May 2008, and involved removing 5-8 cm tall strips of cambium, phloem, and bark from each bole. This was done by a team of chainsaw operators (who made two parallel cuts around the circumference of each bole) and a team of bark removers, who used crowbars to pry and peel the girdled bark strips from the trees. The stem-girdling treatment typically causes mortality of Populus spp. within 1 to 3 years and prevents the prolific root-sprouting ("suckering") behavior of this genus that is associated with cutting the trees down [Burns and Honkala, 1990]. This is an important distinction between our experimental disturbance, which mimics the gradual, in-place mortality that might be expected from a fungal disease or a series of defoliation events, and the silvicultural treatments most often applied to early successional forests in this region, which remove stems, open the canopy and stimulate suckering, and regenerate new cohorts of early successional species.

[7] We are assessing biogeochemical disturbance impacts by comparing $\mathrm{C}$ and $\mathrm{N}$ cycling in the treated (disturbed) area with a nonmanipulated control area. Ground-based measurements are conducted in 16 permanent plots nested within the footprints of separate treatment and control meteorological towers, which measure the net ecosystem $\mathrm{CO}_{2}$ exchange (NEE, the tower-based measure of NEP) between forest and atmosphere. The treatment tower is positioned to the east (predominantly downwind) of the main 33 ha experimental disturbance area while the control tower is in the nonmanipulated forest $2 \mathrm{~km}$ to the west. Each of the towers is surrounded by a circular, 1.1 ha permanent plot of average landscape-level soil fertility, aboveground biomass, and species composition. Smaller plots ( $0.1 \mathrm{ha})$ are established at $100 \mathrm{~m}$ intervals along transects that radiate out from the meteorological towers, encompassing landscapelevel variations in biotic and abiotic properties. Statistical comparisons between treatments are made using a pairedplot design, in which the eight treatment and eight control plots most similar in canopy species composition and productivity were selected from a larger pool $(n=73)$ prior to girdling and matched using principal components analysis (PCA). The PCA was conducted using plot-level leaf litterfall as a measure of species composition (relative abundances of species groups). The first principal component axis corresponded to a gradient of maple versus oak + pine relative abundance, while the second axis defined a gradient in the relative abundance of aspen + birch. After using the PCA to find paired plots along these gradients of species composition, an additional filter was applied to ensure that paired plots had similar levels of productivity (assessed by similarity of plot-level total litterfall, the leaf area index (LAI)). Therefore, in addition to spanning landscape-level variations in species composition, the final plot pairs span a wide productivity gradient, with pretreatment LAI ranging from $\sim 2$ to 7 . Within the final set of paired plots, the two plots of each pair differed from one another by $0 \%-18 \%$ in the similarity of their total LAI and in the relative abundances of the species groups. Most of the differences between plots were $<10 \%$, and these differences were never directional with regards to treatment.

[8] Because this paper presents results from many collaborative projects occurring within the larger framework of the experimental manipulation, the number of paired plots used for measurement and analysis varies among different measurements. For example, some response metrics, such as fineroot nonstructural carbohydrate (NSC) content, are derived from spatially intensive sampling in the two 1.1 ha plots (control and disturbed; note further details about this analysis in section 2.10). Other measurements, such as LAI, were made on all 16 plots, and still others, such as NEE, are integrated landscape measures with no plot-based replication.

\subsection{Soil Respiration and Environmental Parameters}

[9] We concurrently measured soil respiration $\left(R_{s}\right)$, soil temperature $\left(T_{s}\right)$, and volumetric moisture content $\left(\theta_{s}\right)$ in 16 paired control and treatment plots to determine how disturbance modified rates of belowground $\mathrm{C}$ cycling and associated environmental drivers. Point measurements of $R_{s}$, $T_{s}$, and $\theta_{s}$ were made in summer 2009 in 4 and 8 subsampling locations within the 0.1 ha and 1.1 ha plots following the work of Curtis et al. [2005], except that in the present study $T_{s}$ was measured at a $7.5 \mathrm{~cm}$ depth and $\theta_{s}$ was measured to $20 \mathrm{~cm}$ with a CS620 soil moisture probe (Campbell Scientific, Inc., Logan,Utah). Soil respiration was measured with a LI-COR 6400 fitted with a soil cuvette. Site-level air temperature and precipitation were measured at a meteorological station on the UMBS campus, $\sim 2 \mathrm{~km}$ from the study area, facilitating comparison of longterm (1979-present) averages with growing season conditions during the 2007-2009 study period.

\subsection{Fine-Root Nonstructural Carbohydrates}

[10] We quantified fine-root nonstructural carbohydrate (NSC) concentrations to determine whether stem girdling reduced belowground labile $\mathrm{C}$ allocation, a $\mathrm{C}$ flux essential for sustaining root and rhizosphere metabolic processes [Gough et al., 2009]. Fine roots were collected between 0800 and 1000 on 9 July 2009 in the control and treatment 1.1 ha plots, using a $7 \mathrm{~cm}$ diameter corer to obtain and pool three forest floor monoliths $(2-5 \mathrm{~cm}$ thick) at 24 randomly selected locations in each plot. Forest floor samples were stored at $-80^{\circ} \mathrm{C}$, thawed individually, and gently washed to isolate roots $0.5-2.0 \mathrm{~mm}$ diameter. These fine roots were then lyophilized and ground in a ball mill. Fine-root NSC concentrations were measured according to a method adapted from the work of Jones et al. [1977] for use on Populus tissues [Curtis et al., 2000; Gough et al., 2009], which quantifies soluble sugars and starch (sum = total NSC). The method entails extracting soluble sugars from powdered fine roots with ethanol, digesting residual starch, and reading both NSC fractions as glucose equivalents on a 
Spectronic Genesys 2 spectrophotometer (Spectronic Analytical Instruments, Leeds, UK). All forms of nonstructural carbohydrate were converted to a percentage of fine-root dry mass basis for data analysis.

\subsection{Fine-Root Turnover and Biomass}

[11] We quantified fine-root turnover using minirhizotronbased analyses during summer 2009 using methods described in detail by Gough et al. [2008], hypothesizing that girdling would enhance root mortality [Hendrick and Pregitzer, 1993; Johnson et al., 2001]. Briefly, images were collected in June, July, and September 2009 from four minirhizotron tubes each in eight paired control and disturbed plots, providing a time series of $>6500$ fine roots. A portable digital camera with a horizontal visual field of $18 \mathrm{~mm}$ recorded images to a depth of $1 \mathrm{~m}$ (model BTC-2, Bartz Technology Corp, Santa Barbara, California), which were analyzed using Rootracker V2.0 software (Duke University, Durham, North Carolina). Daily fine-root turnover rates for each plot were determined using the LIFETEST Procedure in SAS (SAS V8, SAS Institute, Cary, North Carolina).

[12] We measured fine-root biomasses in six paired plots during 2008 and 2009 . We harvested $225 \mathrm{~cm}^{2}$ of forest floor material at five locations in each plot and then extracted mineral soil in $10 \mathrm{~cm}$ increments to a $20 \mathrm{~cm}$ depth with a $5 \mathrm{~cm}$ diameter corer. We collected $20-40 \mathrm{~cm}$ depth mineral soil from two locations in each plot. Roots were separated from forest floor samples in their field-moist condition, while mineral soil was oven-dried prior to $2 \mathrm{~mm}$ sieving for fine roots. Root mass within each depth increment was scaled by the area sampled to estimate root biomass in $\mathrm{Mg} \mathrm{ha}^{-1}$, and soil bulk densities were checked to verify the collection of a consistent volume of soil within each depth increment across the two years.

\subsection{Forest Floor $\mathbf{N}$ Availability}

[13] We used ion-exchange resin (IER) bags (IERBs) to compare $\mathrm{N}$ availability in soil water percolating out of the forest floors in 14 of the 16 paired plots in 2008 and 2009. IERB methods were based on the works by Hobbie [2005] and Nilsson et al. [2006]. Briefly, each IERB consisted of $30 \mathrm{~mL}$ of Dowex Marathon MR-3 mixed-bed IER beads (Dow Chemical, Midland, Michigan) in a nylon foot stocking (MacPherson Leather, Seattle, Washington), packed into a PVC ring ( $5 \mathrm{~cm}$ diameter, $2 \mathrm{~cm}$ height). To deploy each IERB, we used a square template $\left(225 \mathrm{~cm}^{2}\right)$ to cut the forest floor along three sides and fold the resulting flap of forest floor aside to expose the E horizon. Each IERB was placed within a precisely excavated space at the top of the E horizon, and the flap of forest floor was then folded back into place. We randomly deployed nine ERBs in each plot from 3 July through 17 September 2008 and eight IERBs per plot from 4 June through 9 September 2009. After collection, IERBs were extracted with $100 \mathrm{~mL}$ of $2 \mathrm{M} \mathrm{LiCl}$, and the extract solutions were analyzed for $\mathrm{NH}_{4}-\mathrm{N}$ and $\mathrm{NO}_{3}-\mathrm{N}$ concentrations on a SmartChem 200 (Westco Scientific Instruments, Brookfield, Connecticut) using EPA 350.1 and EPA 353.2 methods, respectively. Inorganic N concentrations were scaled by extract volume, resin mass, and PVC ring area to calculate indices of $\mathrm{NH}_{4}^{+}$and $\mathrm{NO}_{3}^{-}$availability across years and plots.

\subsection{Soil Nitrogen Gas Flux and Leaching}

[14] We measured the efflux of NO from the surface of the forest floor using collars deployed in 12 paired plots using a custom-built chemiluminesence measurement system [McCalley and Sparks, 2008] in order to quantify postgirdling changes in soil $\mathrm{N}$ transformations. In welldrained soils, NO is produced primarily during nitrification as an intermediate product during the series of reactions that oxidize $\mathrm{NH}_{4}^{+}$to $\mathrm{NO}_{3}^{-}$[Davidson et al., 1993; Hall et al., 1996; Russow et al., 2008]. Because it is an intermediate product, we took soil NO efflux to be a measure of the process rate of nitrification rather than the net availability of $\mathrm{NO}_{3}^{-}$, which we measured with IERBs. Measurement collars were PVC pipe $24 \mathrm{~cm}$ in diameter, $18 \mathrm{~cm}$ in height, and inserted to a depth of $9 \mathrm{~cm}$. After measuring baseline $\mathrm{NO}$ partial pressure above the soil surface adjacent to each collar, the collar was covered with a top bearing inlet and outlet ports, thermocouples to monitor soil and ambient temperatures, a relative humidity sensor, and a manometer (model HHP-2080; Omega Scientific, Tarzana, California). Sample air from each collar measurement entered a chemiluminesence NO detector (model 42i TL; Thermo Scientific, West Palm Beach, Florida), which detects light from the reaction between $\mathrm{NO}$ and $\mathrm{O}_{3}$. The system has a detection limit of 50 parts per trillion by volume (pptv), an order of magnitude lower than most NO sensors currently in use in ecological research, and was calibrated daily in the field by sequential dilution of a NO standard (Scott Specialty Gases, Irvine, California). The system is field portable, and power was provided by line power or a generator.

[15] We quantified $\mathrm{N}$ leaching losses with zero-tension lysimeters (ZTLs). In each plot, two clusters, each with three ZTLs, were installed within $2.1 \mathrm{~m}$ of a target tree (a girdled aspen or birch in treatment plots, nongirdled aspen or birch in control plots). Two of the three ZTLs in each cluster were at a $60 \mathrm{~cm}$ depth and the other was at $10 \mathrm{~cm}$; we report only $60 \mathrm{~cm}$ data here. ZTL installation began in 2007, continued in 2008, and all ZTLs acclimated over one winter before being sampled. ZTL samples were collected within 1 week of a rain event during the season of the year without continuous snow cover. Sample processing followed that of McDowell et al. [2004]. Samples were filtered, acidified, and stored at $-30^{\circ} \mathrm{C}$ until analysis. Samples were analyzed for $\mathrm{NO}_{3}^{-}-\mathrm{N}$ and $\mathrm{NH}_{4}^{+}-\mathrm{N}$ in the same manner as IERB extracts. Sample concentration values were averaged in each plot across collection dates to produce a single mean value for each plot in 2008 and 2009. These mean $\mathrm{N}$ concentration values were converted to mass of $\mathrm{N}$ leached to $60 \mathrm{~cm}$ by multiplying by the season average net hydrologic flux, calculated by subtracting seasonal total evapotranspiration from season total precipitation. One assumption that is important to note about this method, which uses seasonal total evapotranspiration as measured by eddy covariance, is that our hydrologic budget does not include runoff. However, we suggest that this assumption is safe at our site, which has coarse-textured soils and a very high infiltration capacity and is not drained by any surface water features.

\subsection{Leaf Area Index}

[16] We estimated plot-level LAIs from measurements of overstory leaf litter mass, which was quantified using three 
litter traps $\left(0.264 \mathrm{~m}^{2}\right)$ in each of the 16 paired plots. Leaf litter was removed from litter traps weekly during leaf abscission and monthly otherwise, separated by species, dried, and weighed. The LAI was calculated as a plot-level mean for each species from its litterfall mass and its specific leaf area (SLA), the latter of which was measured for a subset of leaves of each species during 10 years of litterfall collection with a LI-3100 leaf area meter (LI-COR, Lincoln, Nebraska).

\subsection{Foliar Carbon and Nitrogen}

[17] We used shotguns to sample upper canopy leaves for $\mathrm{C}$ and $\mathrm{N}$ analysis, with slight differences in sampling design between years. In 2007, before PCA plot pairs were established, we sampled one tree each of the dominant species during the first week of September in four plots designated to be girdled, but we did not include these samples in any formal statistical analyses. Rather, since stem girdling was not implemented until the following spring, we used these pretreatment samples to determine whether significant differences between control and treatment green leaf chemistry observed in 2008 and 2009 were likely to have existed prior to stem girdling. In 2008 and 2009, we sampled two to three trees of each species in eight of the paired plots during the final week of August. For every tree's foliar sample, we acquired at least three upper canopy leaves, which were dried at $60^{\circ} \mathrm{C}$, ground in a ball mill, and analyzed at UMBS on a Costech Analytical CHN analyzer (Costech Analytical, Valencia, California) coupled to a Finnigan Delta Plus XL isotope ratio mass spectrometer (Thermo Scientific). Instrument error as checked by repeated internal standards was \pm $0.16 \%$ for $\delta^{15} \mathrm{~N}, \pm 0.38 \%$, for $\delta^{13} \mathrm{C}$, and \pm 0.18 for $\% \mathrm{~N}$ (standard deviations).

\subsection{Net Ecosystem $\mathrm{CO}_{2}$ Exchange, Gross Primary Production, and Ecosystem Respiration}

[18] We used eddy covariance to measure fluxes of $\mathrm{CO}_{2}$ and heat and water vapor between the atmosphere and the forest canopy in control and treatment areas in order to quantify disturbance effects on net annual C storage, or NEE, and its component terms (gross primary production (GPP), and ecosystem respiration $R_{e}$ ) Sensors were deployed at 34 and $46 \mathrm{~m}$ above ground on the control tower and $32 \mathrm{~m}$ on the treatment tower. Wind velocity and temperature fluctuations were measured using three-dimensional sonic anemometers (model CSAT3, Campbell Scientific); $\mathrm{CO}_{2}$ and water vapor concentrations were sampled at $10 \mathrm{~Hz}$ using closed-path infrared gas analyzers (IRGAs) (LI-COR models LI-6262 and LI-7000) and compiled into half-hour block averages of net fluxes following the AmeriFlux protocol (J. W. Munger and H. W. Loescher, Guidelines for making eddy-covariance measurements, 2009, available at http://public.ornl.gov/ ameriflux/sop.shtml, accessed 16 February 2011). Water vapor and $\mathrm{CO}_{2}$ concentrations were adjusted using the Webb, Pearman, and Leuning correction in a modified form derived by Detto and Katul [2007] as a correction for the $10 \mathrm{~Hz}$ time series of the scalar.

[19] Following Curtis et al. [2005], we defined three seasons within each calendar year: dormant, early, and late growing season. The $30 \mathrm{~min}$ data within each season were further divided into daytime and nighttime observations, defined by above canopy photosynthetically active radiation
(PAR) measurements. Data were filtered based on a seasonal frictional velocity $\left(u^{*}\right)$ threshold criterion [Reichstein et al., 2005; Papale et al., 2006], with a prescribed maximum $u^{*}$ threshold of $0.35 \mathrm{~m} \mathrm{~s}^{-1}$ [Schmid et al., 2003]. $R_{e}$ was calculated using site-specific empirical formulas [Curtis et al., 2005], which relate nighttime NEEs to soil moisture and temperature. We used a bilinear periodic method to fill gaps in temperature, moisture, humidity, and radiation observations and assumed that $\mathrm{CO}_{2}$ fluxes during nighttime in all seasons and during the daytime in the dormant season were driven entirely by $R_{e}$. We used the empirical respiration equations to gap-fill NEEs during all nights and dormant season days. Gaps in daytime GPPs during the growing seasons were filled using the mean of 100 neural network simulations [Papale and Valentini, 2003]. A gapfilled GPP was added to $R_{e}$ to provide a gap-filled NEE. Since the treatment tower sampled a footprint larger than the 33 ha of contiguous experimental girdling area, we used a two-dimensional (2-D) footprint model [Hsieh et al., 2003; Detto et al., 2006] that we modified to automatically integrate the flux-source probability over the treatment area and thus provide an index for the treatment footprint probability in each $30 \mathrm{~min}$ block average period. We then used the probabilistic flux footprint climatology [Chen et al., 2009] to scale our conclusions to fluxes originating only from the disturbed area.

[20] Despite the fact that measurements at both sites were done above the canopy, measurements that are conducted within the roughness subdomain, which can extend as high as 4 times the canopy height, can be biased by surface and forest features near the measurement location [Bohrer et al., 2009]. Accordingly, our $\mathrm{CO}_{2}$ flux measurements at 32 and $34 \mathrm{~m}$ were consistently lower than at $46 \mathrm{~m}$, causing the $\mathrm{CO}_{2}$ flux measurements reported in this paper to differ substantially from those previously published from the control tower [e.g., Gough et al., 2008]. In the present analysis, we assessed treatment effects by comparing fluxes measured at $34 \mathrm{~m}$ on the control tower and $32 \mathrm{~m}$ on the treatment tower, which exhibited a 1:1 NEE relationship prior to treatment (not shown).

\subsection{Data Analysis}

[21] For ground-based ecological measurements, we compared treatment means over time using a time series analysis of variance (ANOVA) in which paired control and treatment plots served as blocked replicates. Our paired-plot design accounted for spatial variations in ecological processes and their treatment effects by capturing the inherent variability in response parameters within the treatment and control areas. A $t$ test (two-sample rather than paired) was used for fine- root NSC concentrations because this response statistic was measured only on a single date and because we treated the 24 samples from each of two plots as replicates, rather than the plots themselves. We conducted statistical analyses using SAS and SigmaPlot (SAS Inc., Cary, North Carolina; SYSTAT Inc., San Jose, California). For all analyses, we used $P=0.05$ as the threshold for statistical significance, and for all ANOVA tests requiring pairwise contrasts we used Fisher's least significant difference (LSD).

[22] We quantified uncertainty in $\mathrm{C}$ cycling parameters derived from meteorological tower data by accounting for random errors in the flux measurements using the 


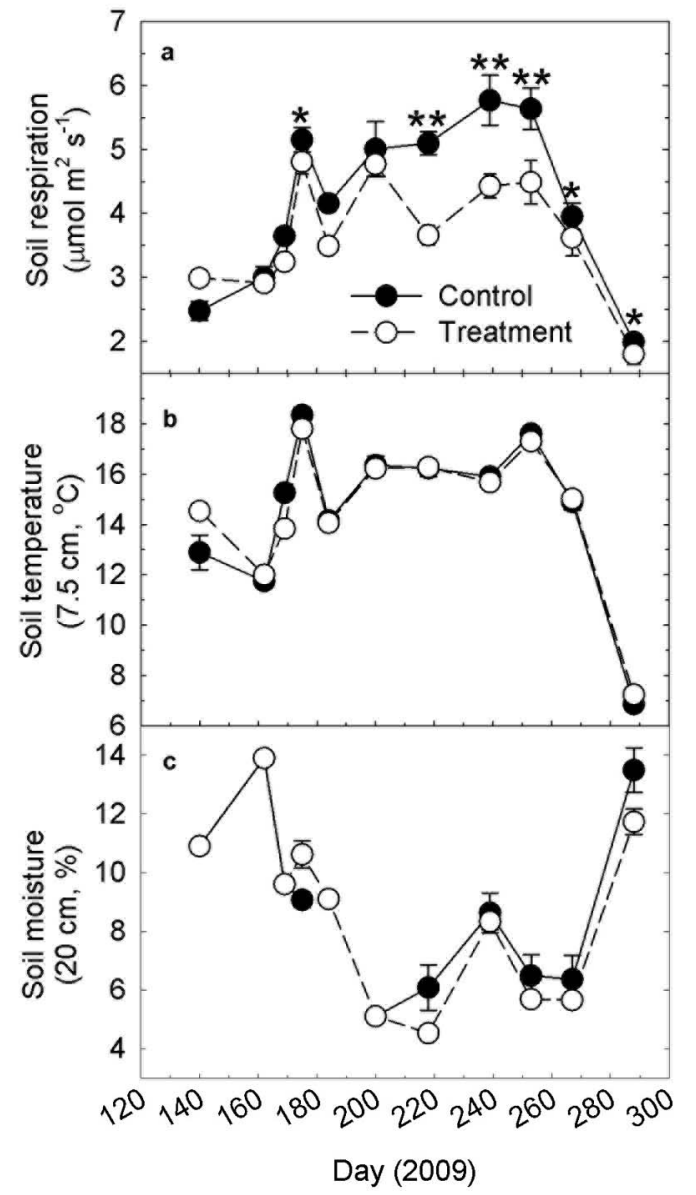

Figure 2. Seasonal dynamics of mean $( \pm \mathrm{SE})$ (a) daily soil respiration rates, (b), temperature, and (c) moisture from nondisturbed (control) and disturbed (treatment) plots, 2009. A single asterisk indicates $P<0.05$; two asterisks indicate $P<0.01$.

daily differencing approach developed by Hollinger and Richardson [2005]. This assumes flux measurements made at the same time on consecutive days, under similar environmental conditions (half hourly means of PAR within $75 \mu \mathrm{mol} \mathrm{m}{ }^{-2} \mathrm{~s}^{-1}$, temperature within $3^{\circ} \mathrm{C}$, and wind speed within $1.0 \mathrm{~m} / \mathrm{s}$ ), will be equivalent. We expand on their random error approach by incorporating the random error associated with our gap-filling techniques for $R_{e}$ and GPP, providing a more conservative estimate of random error. Errors of $R_{e}$ are pulled from the regression of our empirical $R_{e}$ formulas. Errors for GPP were found from the standard error of the 100 neural network GPP simulations. A weighted average of these three half-hour random errors is used to integrate yearly and seasonal random errors and to process specific random errors.

\section{Results}

\subsection{Belowground C Cycling}

[23] Concurrent reductions in soil respiration, fine-root NSC concentrations and biomass, and an increase in fine-root turnover indicate that stem girdling of early successional aspen and birch trees initiated a cascade of interrelated changes in belowground C cycling. Soil respiration of control and treatment plots began to diverge during midsummer 2009 (the second growing season following experimental treatment), providing a broadly integrated signal of the effect of stem girdling on belowground $\mathrm{C}$ cycling processes, with fluxes up to $39 \%$ lower in the treatment area (Figure 2a). Significant differences in soil respiration between treatments persisted for the remainder of the 2009 measurement period and into the dormant season. Soil temperature and moisture, two primary modulators of soil respiration at our site [Curtis et al., 2005], varied substantially over time (Figures $2 \mathrm{~b}$ and 2c), but did not significantly differ between treatments. Coincident with soil respiration declines, the girdling treatment significantly reduced NSC allocation to fine roots, while prompting an increase in fine root turnover. Fine roots from the disturbed stand had significantly lower NSC concentrations than those in the control area (Figure $3 \mathrm{a} ; P<0.05$ ). This pattern of lower NSC concentrations in disturbed plot fine roots coincided with elevated rates of fine-root turnover during summer 2009 (Figure 3b). From June through August, fine-root turnover was 10-fold higher in disturbed than control plots. This acceleration of fine-root turnover occurred without net replacement at $10-20 \mathrm{~cm}$ soil depth, as indicated by significant reductions in fine-root biomass in disturbed plots from 2008 to 2009 (Table 2). Overall, patterns of postdisturbance belowground $\mathrm{C}$ cycling show that girdling decreased belowground labile $\mathrm{C}$ allocation, which in turn caused declines in root mass and soil respiration.

\subsection{Belowground $\mathbf{N}$ Cycling}

[24] Significant postdisturbance shifts in belowground N availability, cycling, and leaching, particularly in 2009, indicate partial decoupling of belowground $\mathrm{C}$ and $\mathrm{N}$ cycles shortly after implementation of the girdling treatment. Forest floor $\mathrm{NH}_{4}^{+}$availability was slightly, though not significantly elevated in treatment relative to control plots in 2008, a

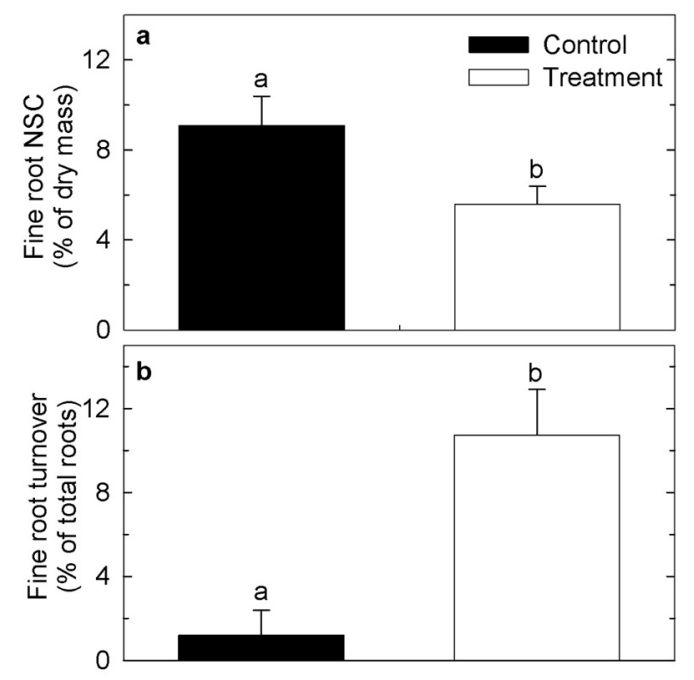

Figure 3. Fine-root nonstructural carbohydrate (NSC) (a) concentrations and (b) turnover rates for control and treatment plots, summer 2009. Bars are means \pm SE, and $P$ values denote the significance of the treatment effect. Fine roots for NSC analysis were collected in July; turnover rates refer to the period from June to September. 
Table 2. Fine Root Biomass by Year, Treatment, and Soil Depth, With Proportional Changes from 2008 to $2009^{\mathrm{a}}$

\begin{tabular}{lccccccc}
\hline & \multicolumn{3}{c}{ Control } & & \multicolumn{3}{c}{ Treatment } \\
\cline { 2 - 4 } \cline { 7 - 8 } \multicolumn{1}{c}{ Depth } & 2008 & 2009 & Percent Change & & 2008 & 2009 & Percent Change \\
\hline Forest floor & $3.3[0.37]$ & $3.1[0.39]$ & -7 & & $3.6[0.56]$ & $3.2[0.49]$ & -11 \\
$0-10$ & $3.6[0.57]$ & $2.6[0.31]$ & -30 & & $2.5[0.55]$ & $1.4[0.16]$ & -43 \\
$10-20^{\mathrm{b}}$ & $2.7[0.28]$ & $2.1[0.16]$ & -21 & & $2.4[0.36]$ & $1.4[0.17]$ & -44 \\
$20-40$ & $2.9[0.76]$ & $2.5[0.34]$ & -14 & & $2.9[0.56]$ & $2.1[0.72]$ & -27 \\
\hline
\end{tabular}

${ }^{\mathrm{a}}$ Biomass values are in $\mathrm{Mg} \mathrm{ha}^{-1}$, with standard errors in brackets.

${ }^{b}$ Denotes significantly different rate of interannual change between treatments in this layer, as determined by repeated measures ANOVA on paired-plot fine root biomass (see section 2.1).

difference that became highly significant in $2009(P<$ $0.001)$ as treatment $\mathrm{NH}_{4}^{+}$availability increased dramatically (Figure 4a). Soil surface NO efflux (Figure 5) responded similarly to $\mathrm{NH}_{4}^{+}$availability, with marginally and then significantly higher rates in the treatment area during the two growing seasons following girdling $(P<0.01)$. Forest floor $\mathrm{NO}_{3}^{-}$availability was significantly higher in disturbed than in control plots in $2008(P<0.01)$, a treatment effect that ceased in 2009 (Figure 4b). Nonetheless, $\mathrm{NO}_{3}^{-}$leaching to $60 \mathrm{~cm}$ depth was significantly higher in treatment than control plots in 2009 (Figure 6; $P<0.05$ ), although it was not possible to directly compare treatment and control $\mathrm{NO}_{3}^{-}$ leaching in 2008 because of incomplete lysimeter installation. Collectively, the numerous changes in belowground $\mathrm{N}$ cycling processes indicate that stem girdling of early successional canopy dominant trees disrupted formerly tight linkages between belowground $\mathrm{C}$ allocation and soil $\mathrm{N}$ transformations, with detectable but minimal effects on soil $\mathrm{N}$ retention.

\subsection{Canopy LAI and Physiology}

[25] Shifts in LAIs from 2008 to 2009 indicate dynamic changes in the canopy of the treatment area following disturbance. Total LAIs in the control and treatment plots did not change significantly from one year to the next despite a coincident decline in treatment plot aspen and birch LAIs (Figure 7). We observed a significant 1 year decrease in aspen and birch LAIs of $29 \%$ in treatment plots, a rate $2.6 \times$ that of the control. Maintenance of total leaf area in the treatment area indicates that precipitous declines in early successional aspen and birch LAIs were offset by rapidly proliferating leaf areas from later successional species.

[26] Foliar ${ }^{13} \mathrm{C}$ signatures of the three dominant species (aspen, maple, oak) provided a mechanistic insight into the cause of aspen and birch decline postgirdling, with foliar $\delta^{13} \mathrm{C}$ enrichment signaling plant water stress [Sparks and Ehleringer, 1997]. High relative $\delta^{13} \mathrm{C}$ enrichment of girdled aspen foliage in 2009 indicates that girdling-induced water stress contributed to the accelerated decline of this early successional species (Figure 8a). The significant treatment effect on aspen foliar $\delta^{13} \mathrm{C}$ in 2008 and $2009(P<$ $0.01)$ was not evident for either of the other two later successional, nongirdled species. Although girdling significantly enriched foliar $\delta^{13} \mathrm{C}$ only in aspen, all species showed substantial interannual variations, with maple, oak, and (nongirdled) aspens exhibiting their most enriched foliar $\delta^{13} \mathrm{C}$ during the warm, droughty summer of 2007 (Table 3).

[27] Foliar N concentrations lend additional insight into the cause of accelerated decline of early successional aspen, as well as the effects of enhanced belowground $\mathrm{N}$ availability in disturbed plots on later successional species and their LAI proliferation. Stem girdling decreased N uptake by bigtooth aspen (Figure 8b), causing significantly lower foliar $\% \mathrm{~N}$ in treatment relative to control plots in 2008 and 2009 (treatment $P<0.001$ ). Red maple showed the opposite pattern, with significantly elevated foliar $\% \mathrm{~N}$ in treatment compared with that of control plots $(P<0.05)$. The tendency for red oak to have slightly higher foliar $\% \mathrm{~N}$ in treatment

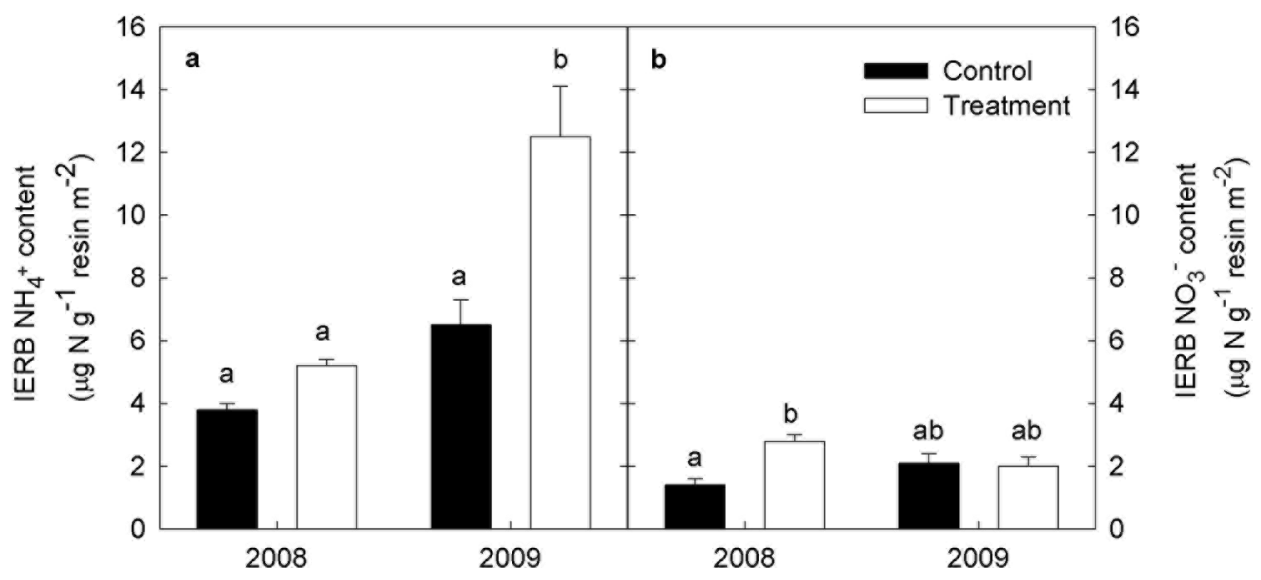

Figure 4. Interannual variation in and treatment effects on forest floor $\mathrm{N}$ availability, as measured by ion-exchange resin bags (IERBs). Bars are means $\pm \mathrm{SE}$ of IERB for (a) $\mathrm{NH}_{4}^{+}$content and (b) $\mathrm{NO}_{3}^{-}$content. The superscripts above each error bar denote significantly different groups $(\mathrm{P}<0.05)$. 


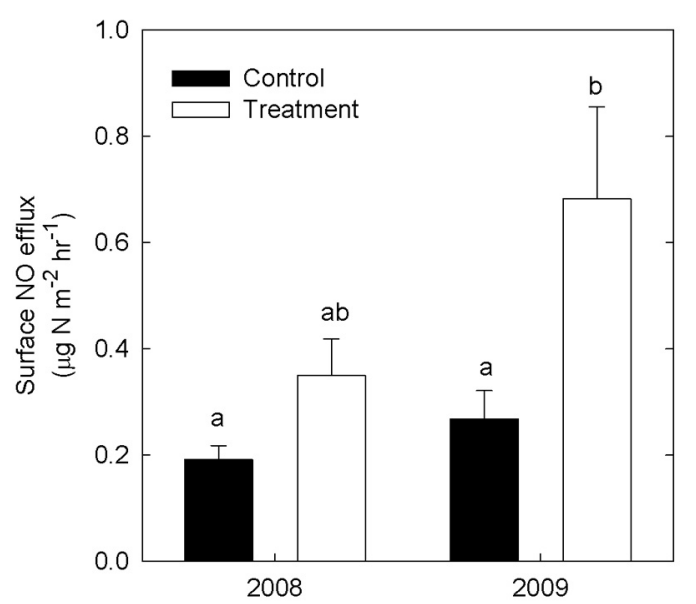

Figure 5. Interannual variation in and treatment effects on NO efflux from the surface of the forest floor. Bars represent means \pm SE, and the superscripts above each error bar denote significantly different groups $(\mathrm{P}<0.05)$.

than control plots was not significant. Altogether, stem girdling decreased the ability of early successional aspen to acquire $\mathrm{N}$ for foliage, while increased red maple foliar $\mathrm{N}$ in the treatment area indicates that this species was an important $\mathrm{N}$ sink during aspen senescence.

[28] Following stem girdling, pervasive foliar ${ }^{15} \mathrm{~N}$ enrichment in disturbed plots coincided with elevated rates of belowground $\mathrm{N}$ cycling and loss, a pattern commonly observed under conditions of fast or leaky $\mathrm{N}$ cycling [Craine et al., 2009; Högberg, 1990]. All three species sampled exhibited higher foliar $\delta^{15} \mathrm{~N}$ in treatment than control plots (Figure 8c), although these differences constituted significant treatment effects for later successional red maple $(P<0.05)$ and red oak $(P<0.01)$, but not the declining bigtooth aspen. In addition, all three species showed significant interannual variations in foliar $\delta^{15} \mathrm{~N}$ between 2008 and 2009. Specifically, aspen and oak from both treatments became more ${ }^{15} \mathrm{~N}$ enriched $(P<0.001)$ during that interval, while red maple became significantly

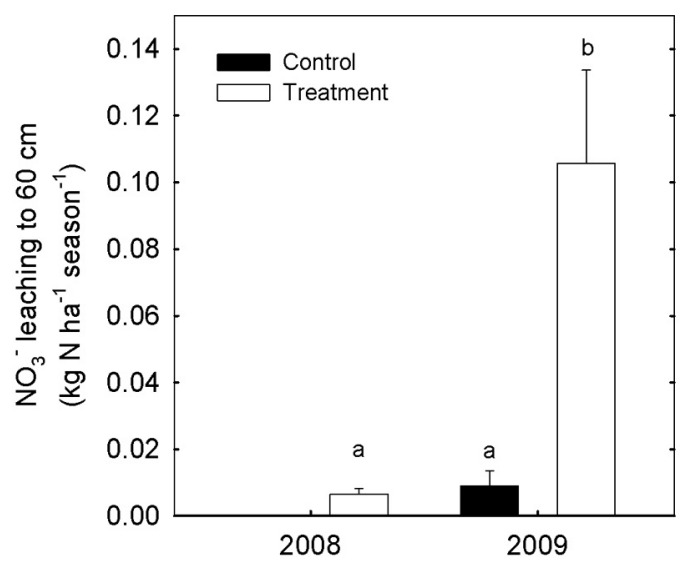

Figure 6. $\mathrm{NO}_{3}-\mathrm{N}$ leaching to $60 \mathrm{~cm}$ depth in disturbed and control areas. Bars represent means $\pm \mathrm{SE}$, and the superscripts above each error bar denote significantly different groups $(\mathrm{P}<0.05)$. Control data were not available in 2008 .

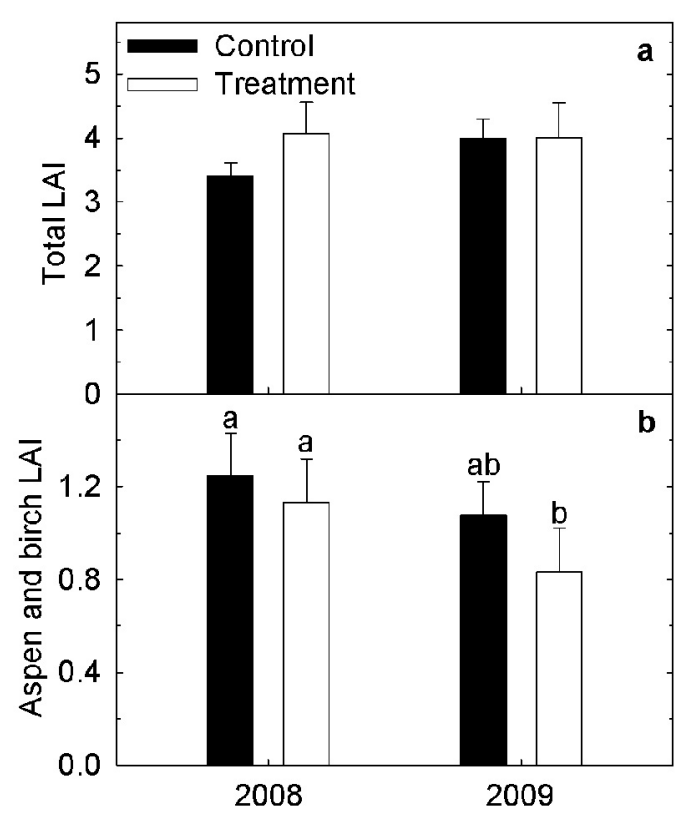

Figure 7. Leaf area index (LAI) for (a) whole canopies and (b) early successional species only (aspen + birch), 2008 and 2009. Bars are means \pm SE, and the superscripts above each error bar denote significantly different groups $(\mathrm{P}<0.05)$.

more depleted $(P<0.01)$. Foliar $\delta^{15} \mathrm{~N}$ values of all three species in treatment plots in 2007 (before girdling) were comparable to 2008-2009 control plot values, with treatment aspen and oak showing increasing ${ }^{15} \mathrm{~N}$ enrichment in 2008 and 2009 relative to this pretreatment baseline. In synthesis, formal paired-plot (treatment versus control plots in 2008 and 2009) and informal a posteriori comparisons (treatment plot posttreatment versus pretreatment) suggested that stem girdling caused general ${ }^{15} \mathrm{~N}$ enrichment within the source $\mathrm{N}$ pools for foliage, with interannual and interspecific variations also contributing to the observed patterns.

\subsection{NEE, GPP, and $R_{e}$}

[29] Interannual patterns of NEE in the control and treatment areas diverged two years following girdling, with NEE declining in the treatment footprint and increasing slightly in the control forest during the 2009 growing season (Figure 9). The treatment area NEE was $0.6 \mathrm{MgC} \mathrm{ha}^{-1} \mathrm{yr}^{-1}$ higher than that of the control forest during the 2007 and 2008 growing seasons, exhibiting little change from one year to the next. In contrast, the treatment area NEE declined from growing season 2008 to 2009 by $9 \%$ while concurrently increasing in the control area by $4 \%$, resulting in near convergence of disturbed and control NEE in 2009. Although dormant season NEE, which was dominated by ecosystem respiration, was consistently more negative in the treatment area than in the control area, year-to-year shifts in treatment and control NEE from 2007 to 2009 were parallel and suggest no treatment effect outside of the growing season. The reduction in growing season NEE in the treatment area from 2008 to 2009 was caused by steeper declines in GPP than in $R_{e}$ (Figure 10). The magnitude of GPP and $R_{e}$ varied considerably across years and between treatments. However, these two large oppos- 

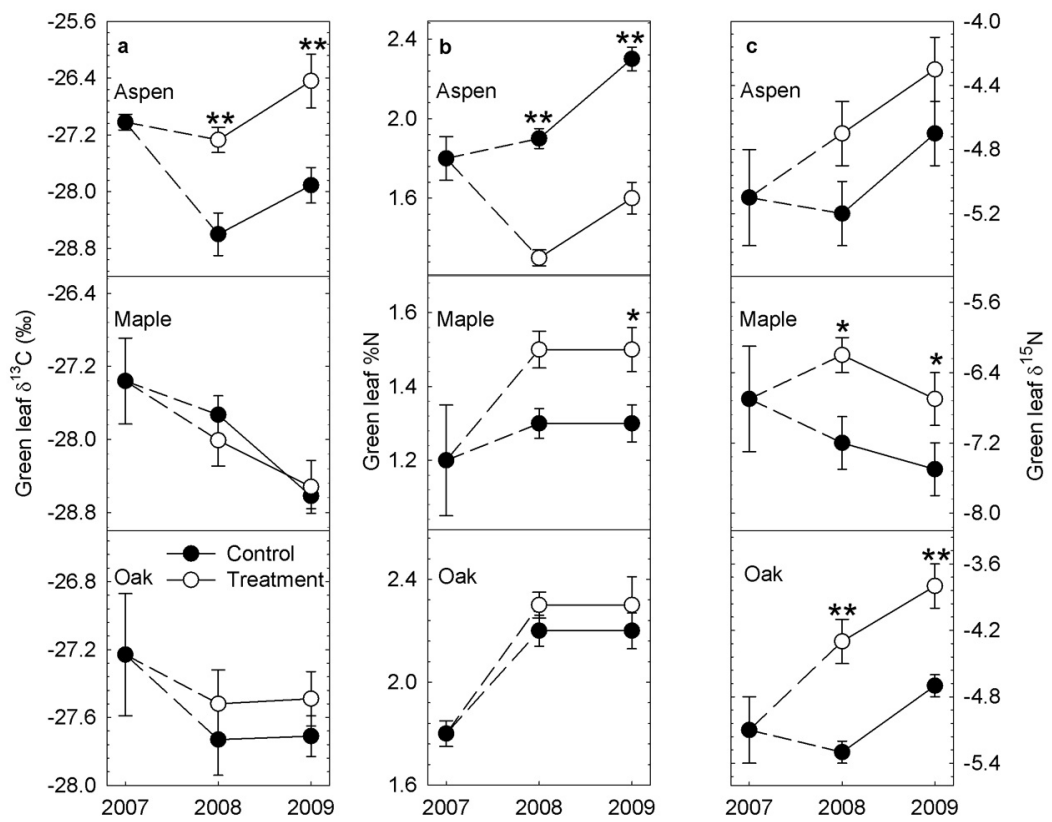

Figure 8. (a) Foliar $\delta^{13} \mathrm{C}$, (b) $\% \mathrm{~N}$, and (c) $\delta^{15} \mathrm{~N}$ of the three dominant tree species at UMBS. Plots show means \pm SE. Values from 2007 are pretreatment data from treatment plots, while 2008-2009 values are from paired treatment and control plots. Asterisks represent significantly different control versus treatment means (see Figure 2 for $P$ values).

ing fluxes moved in parallel within treatments from 2007 to 2008 before diverging slightly in the 2009 growing season and prompting a modest decline and increase in treatment and control NEE, respectively.

\section{Discussion}

[30] Our experimental treatment directly affected only a fraction of mature canopy trees, mimicking disturbances such as pathogenic insects or fungi that target trees of a particular species within a mixed canopy and cause them to die over the course of several years [Hancock et al., 2008; Nuckolls et al., 2009]. Because of the patchiness and subtle intensity of our experimental disturbance, which targeted only early successional tree species, its impacts on ecosystem $\mathrm{C}$ uptake and $\mathrm{N}$ leaching were modest, and will likely be short-lived because of rapid compensatory growth and $\mathrm{N}$ uptake by later successional trees. This rapid resilience in ecosystem-scale $\mathrm{C}$ and $\mathrm{N}$ cycles and the maintenance of relatively tight coupling between the two biogeochemical cycles set our experimental disturbance apart from more commonly studied severe events [Bormann and Likens, 1979; Gough et al., 2007; Kashian et al., 2006; Wirth et al., 2002].

Table 3. Mean Air Temperature and Accumulated Precipitation for Meteorological Summer (June, July, August) at UMBS ${ }^{\text {a }}$

\begin{tabular}{lcc}
\hline \multicolumn{1}{c}{ Year } & Temperature $\left({ }^{\circ} \mathrm{C}\right)$ & Precipitation $(\mathrm{mm})$ \\
\hline 2007 & 20.5 & 188 \\
2008 & 19.4 & 229 \\
2009 & 17.9 & 254 \\
$1979-2010$ & 17.8 & 219 \\
\hline
\end{tabular}

${ }^{\mathrm{a}}$ Study years are shown individually, and a long-term average is given for comparison.
In addition, the divergent responses indicate improved biogeochemical understanding of subtle disturbances and the mechanisms directing functional resilience are important for accurately projecting disturbance effects on $\mathrm{N}$ cycling and the
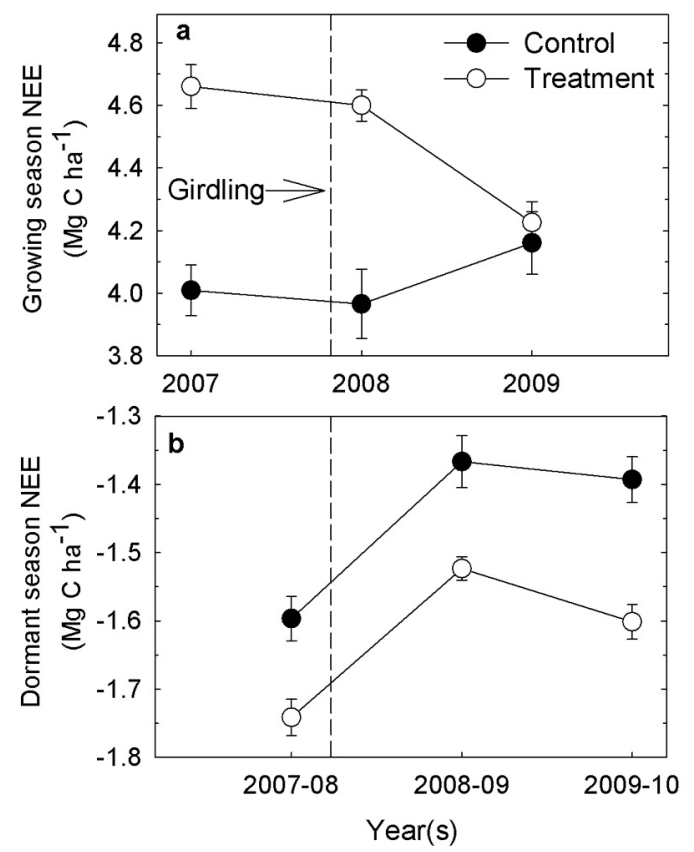

Figure 9. Net ecosystem $\mathrm{CO}_{2}$ exchange (NEE) in the control and treatment meteorological tower flux footprints during the (a) growing and (b) dormant seasons before and following the girdling of mature aspen and birch, 20072009. Note that positive NEE values correspond to net $C$ uptake by the forest. 


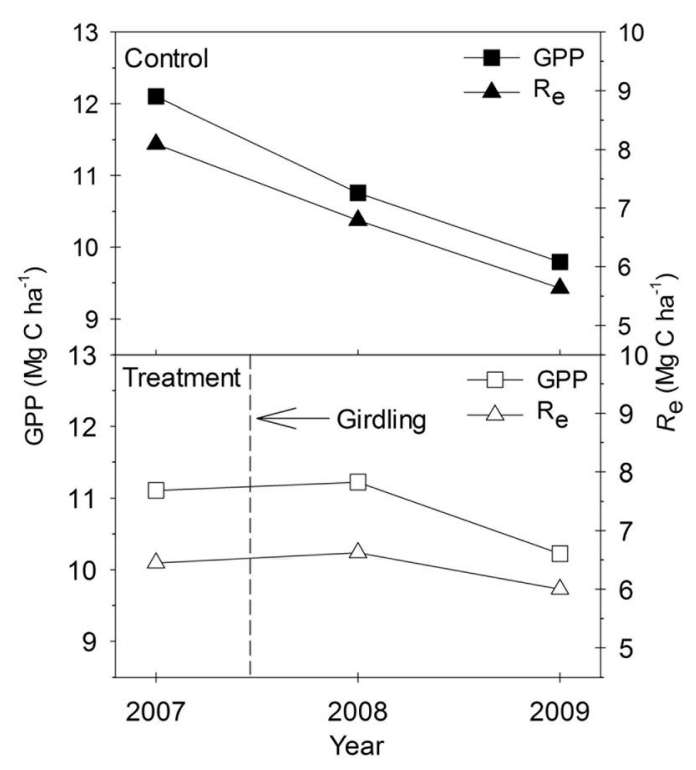

Figure 10. Growing season gross primary production (GPP) and ecosystem respiration $\left(R_{e}\right)$ in the (a) control and (b) treatment meteorological tower flux footprints before and following the girdling of mature aspen and birch, 2007-2009.

terrestrial C sink over space [Magnani et al., 2007; Thornton et al., 2002] and time [Aber et al., 2002; Law et al., 2001].

[31] Our study identifies a mechanism that makes coupled $\mathrm{C}$ and $\mathrm{N}$ cycling resilient to subtle forest disturbances. Specifically, the presence of abundant later successional trees that were not directly affected by the experimental disturbance was an efficient means for retaining the actively cycling soil $\mathrm{N}$ that was no longer being accessed by the early successional species. Rapid, efficient redistribution of $\mathrm{N}$ from the senescing aspens and birches to the longer-lived later successional trees allowed the avoidance of ecologically significant $\mathrm{N}$ leaching during the disturbance period. Although the 10-fold increase in $\mathrm{NO}_{3}^{-}$leaching in our experiment (disturbed versus reference plots) was similar in magnitude to that of more severe disturbances [Gundersen et al., 2006], the quantity of $\mathrm{NO}_{3}^{-}$leached was considerably smaller $\left(<0.2\right.$ versus $\sim 10$ to $\left.>40 \mathrm{~kg} \mathrm{NO}_{3}-\mathrm{N} \mathrm{ha}^{-1} \mathrm{yr}^{-1}\right)$. Compared with that of studies from similar North American forests, leaching in FASET treatment plots was closer to values from small gaps and edges $\left(0.2-1.3 \mathrm{~kg} \mathrm{NO}_{3}-\mathrm{N} \mathrm{ha}^{-1} \mathrm{yr}^{-1}\right)$ [Scharenbroch and Bockheim, 2008] than from severely defoliated or clear-cut forests $\left(20-40 \mathrm{~kg} \mathrm{NO}_{3}-\mathrm{N} \mathrm{ha}^{-1} \mathrm{yr}^{-1}\right)$ [Houle et al., 2009; Pardo et al., 2002]. Together, minor inorganic $\mathrm{N}$ losses from this $\mathrm{N}$-limited forest and the slight decrease in $\mathrm{C}$ uptake differentiate our experiment from studies that examined early effects of severe disturbances, which exhibit large $\mathrm{N}$ losses and/or substantially reduced forest production [Bormann and Likens, 1979; Chertov et al., 2009; Davis et al., 2003; Gough et al., 2007; Gundersen et al., 2006; Law et al., 2001].

[32] Our experiment identifies a suite of interdependent, process-level changes in forest biogeochemistry and structure following disturbance, which ultimately led to nearcomplete $\mathrm{N}$ retention and, consequently, avoided a precipitous decline in $\mathrm{C}$ storage. The first impact of disturbance was to decrease belowground $\mathrm{C}$ allocation, evidenced by declines in soil respiration, root NSC pools, and fine-root biomass. By physically preventing the transport of photosynthate belowground, much as larval insect galleries do, stem girdling decreases soil respiration [Frey et al., 2006; Högberg et al., 2001; Scott-Denton et al., 2006] and root NSC pools, which are essential to belowground metabolic processes. In our disturbed site, a decline in root NSC compromised root metabolism, thereby accelerating fine-root turnover and decreasing root biomass. Decreased fine root biomass has been observed following stem girdling or thinning [Sullivan et al., 2008; Nuckolls et al., 2009; Tian et al., 2009], although root proliferation by healthy trees may compensate [Dore et al., 2010]. Overall, the net effect of experimental disturbance on the belowground $\mathrm{C}$ cycle in our study was to temporarily decrease the amount and ability of roots to maintain essential functions, opening the door for perturbations to the belowground $\mathrm{N}$ cycle.

[33] Decreased belowground $\mathrm{C}$ allocation following disturbance increased belowground $\mathrm{N}$ availability and cycling rates, although these changes had only modest effects on belowground $\mathrm{N}$ retention. Increased $\mathrm{NH}_{4}^{+}$availability is a common effect of disturbance, which decreases rates of photosynthate-driven, ammonium-consuming processes, including root, mycorrhizal, and microbial uptake [Johnson and Edwards, 1979; Lindahl et al., 2010; Zeller et al., 2008]. Higher soil NO emissions indicate that the soil microbial community responded to elevated $\mathrm{NH}_{4}^{+}$availability with accelerated nitrification rates, which also have been observed following wildfires and clear-cuts [Holmes and Zak, 1999; LeDuc and Rothstein, 2007; Westbrook and Devito, 2004]. In disturbed plots, accelerated forest floor nitrification exceeded $\mathrm{NO}_{3}^{-}$consumption by roots, mycorrhizae, and microbes, causing elevated $\mathrm{NO}_{3}^{-}$availability in 2008, $\mathrm{NO}_{3}^{-}$leaching in 2009, and foliar ${ }^{15} \mathrm{~N}$ enrichment in the three dominant tree species in both years. Foliar ${ }^{15} \mathrm{~N}$ enrichment indicates $\mathrm{NO}_{3}^{-}$losses from the rooting zone inorganic $\mathrm{N}$ pool [Högberg, 1990], but the modest degree of enrichment in our study $(0.4 \% 0-1.0 \% 0)$ contrasts with more intense forest disturbances $(2 \%-4 \%$ in the works by Pardo et al. [2002] and Smaill et al. [2009]). This faint isotopic fingerprint of $\mathrm{N}$ leaching underscores the subtlety that sets our low-intensity experimental disturbance apart from more severe events: Despite elevated $\mathrm{NO}_{3}^{-}$leaching, most $\mathrm{N}$ in the actively cycling inorganic pool was retained, enabling redistribution to rapidly proliferating, later successional tree canopies.

[34] As disturbance accelerated the decline of early successional species and consequently decreased their demand for $\mathrm{N}$, increased $\mathrm{N}$ availability allowed later successional species to access more soil $\mathrm{N}$ in support of new leaf area production. In disturbed plots, decreases in early successional species' LAIs were concurrent with declining fineroot mass, and the foliar ${ }^{13} \mathrm{C}$ enrichment prevalent among girdled aspens was not noted for other species, suggesting heightened water stress as senescent fine roots deteriorated [Zwieniecki et al., 2000, 2004]. As their root function declined, girdled aspens also reduced $\mathrm{N}$ uptake and allocation to foliage. Girdled aspens had significantly lower foliar $\% \mathrm{~N}$ than those from control plots, a pattern opposite that observed for later successional red maple and one that suggests rapid reallocation and retention of $\mathrm{N}$ within the 
canopy as $\mathrm{N}$ availability increased. These results indicate that later successional trees comprised an important $\mathrm{N}$ sink, a common ecological role of residual vegetation during periods of disturbance-enhanced $\mathrm{N}$ availability [Likens et al., 1970; Swank et al., 2001]. With efficient retention and redistribution of canopy $\mathrm{N}$ and consequent maintenance of total canopy LAI, we observed only a subtle growing season NEE decline $(-9 \%)$ in the disturbed forest that was well within the bounds of climate-driven interannual variation [Gough et al., 2008]. Temperate forests disturbed by partial canopy defoliation from wind or insects also exhibited NEE declines [Allard et al., 2008; Clark et al., 2010], although such changes typically are of smaller magnitude and shorter duration than stand-replacing disturbances [Amiro et al., 2010]. Comparable to that of other partial canopy defoliation studies, our experiment's slight NEE decline was caused by a greater decrease in GPP, which is largely constrained by LAI, than in $R_{e}$ [Amiro et al., 2010; Dore et al., 2010; Misson et al., 2005]. We note, however, that treatment effects on NEE are expected to change over time as lagged consequences of disturbance, such as the delayed decomposition of dead trees, alter the balance between GPP and $R_{e}$. Modest changes in $R_{e}$ two years following treatment reflect short-term changes in the rhizosphere metabolism of dying trees; however, we anticipate that $R_{e}$ will increase as dead trees, now standing, fall and come into contact with moist soils that prime wood decomposition [Martin et al., 2005]. Indeed, decomposition and resulting respiration rates of aspen woody debris at our site are highly dependent on moisture content [Gough et al., 2007].

[35] In summary, we have used an experimental approach to elucidate mechanisms promoting biogeochemical resilience in a subtly disturbed forest. Our experimental disturbance simulated natural processes that target the early successional canopy dominants, decreasing belowground $\mathrm{C}$ allocation but allowing for efficient redistribution of actively cycling $\mathrm{N}$ away from these senescing early successional species to later successional trees. Because the senescence induced by experimental disturbance was diffuse over space and time during this 2 year study period, the forest avoided the large $\mathrm{N}$ losses that cause $\mathrm{C}$ storage to decline following severe disturbances. Severely disturbed forests may recover lost $\mathrm{N}$ stocks and return to predisturbance levels of $\mathrm{C}$ storage over time scales of decades to a century [Bormann and Likens, 1979; Kashian et al., 2006], but that our subtly disturbed forest seems to be averting this intervening period of decreased $\mathrm{N}$ availability and production suggests it is on a track toward biogeochemical reorganization much sooner and with a greater share of actively cycling $\mathrm{N}$ still intact than if it had been severely disturbed. This has broader implications for the way that forests of similar disturbance history and species composition are managed, because it suggests that it may be possible to remove mature early successional trees while maintaining sufficient site biomass for $\mathrm{N}$ retention and sustained net $\mathrm{C}$ uptake. This approach, typically involving silvicultural prescriptions for various levels of thinning, is a generally accepted way to maintain both timber production and $\mathrm{C}$ sequestration in maturing forests [Gough et al., 2010; Paul et al., 2002; Jandl et al., 2007]. However, we stress that if such management plans were to be implemented for forests like the one we describe in the present experiment, there would be a tight balance to strike between removing enough biomass for a meaningful harvest and not removing so much as to trigger $\mathrm{N}$ leaching, reduced $\mathrm{C}$ uptake, and regeneration of shade-intolerant early successional species.

[36] Looking to the future, we hypothesize that the changes in $\mathrm{N}$ cycling and uptake by later successional trees that have emerged during this disturbance phase have shifted the $\mathrm{N}$ cycle to a fundamentally different, faster track, one that will interact with increasing canopy complexity over successional time to enhance the rates of $\mathrm{C}$ uptake and storage by this forest. Structurally complex forest canopies with multiple layers and many canopy gaps are more efficient at intercepting light than structurally simpler ones and thus may contribute to higher C uptake [Ahl et al., 2004; Ishii et al., 2004; Martin and Jokela, 2004; Duursma and Makela, 2007], and forthcoming observational studies at our site indeed indicate that stands with increased canopy structural complexity and $\mathrm{N}$ availability have higher rates of C storage [Hardiman et al., 2011]. Together these biogeochemical and structural changes following our subtle experimental disturbance may form a mechanistic basis for recent work showing that forests are capable of storing $\mathrm{C}$ for centuries [Luyssaert et al., 2008], redefining our understanding of the biogeochemical functioning and ecosystem services provided by later successional forests.

[37] Acknowledgments. We thank the following individuals for assistance with fieldwork, sample preparation, and analysis: A. Bajcz, L. Billings, C. Bogdan, A. Brenske, A. DeGabriele, A. Do, R. Gondalia, M. Grant, J. Greenbaum, C. Higley, R. Kinney, K. McClure, J. Nietz, C. Rapp, K. Sparks, S. Webster, and Z. Zeneberg. This research is supported by the U.S. Department of Energy's Office of Science (BER) through the Midwestern Regional Center of the National Institute for Climatic Change Research at Michigan Technological University (award DE-FC0206ER64158), the National Science Foundation (awards DEB-0947329, DEB-0911461, DEB-0237674, DGE-0504552, and AGS-0851421), and the USDA-Forest Service (awards 10-JV-11242306-013 and 09-CR11242302-033).

\section{References}

Aber, J. D., S. V. Ollinger, C. T. Driscoll, G. E. Likens, R. T. Holmes, R. J. Freuder, and C. L. Goodale (2002), Inorganic nitrogen losses from a forested ecosystem in response to physical, chemical, biotic, and climatic perturbations, Ecosystems, 5, 648-658, doi:10.1007/s10021-002-0203-2.

Ahl, D. E., S. T. Gower, D. S. Mackay, S. N. Burrows, J. M. Norman, and G. R. Diak (2004), Heterogeneity of light use efficiency in a northern Wisconsin forest: Implications for modeling net primary production with remote sensing, Remote Sens. Environ., 93, 168-178, doi:10.1016/j. rse.2004.07.003.

Allard, V., J. M. Ourcival, S. Rambal, R. Joffre, and A. Rocheteu (2008), Seasonal and annual variation of carbon exchange in an evergreen Mediterranean forest in southern France, Global Change Biol., 14, 714-725, doi:10.1111/j.1365-2486.2008.01539.x.

Amiro, B. D., et al. (2010), Ecosystem carbon dioxide fluxes after disturbance in forests of North America, J. Geophys. Res., 115, G00K02, doi:10.1029/2010JG001390.

Asner, G. P., T. R. Seastedt, and A. R. Townsend (1997), The decoupling of terrestrial carbon and nitrogen cycles, BioScience, 47, 226-234, doi: $10.2307 / 1313076$.

Birdsey, R., K. Pregitzer, and A. Lucier (2006), Forest carbon management in the United States: 1600-2100, J. Environ. Qual., 35, 1461-1469, doi:10.2134/jeq2005.0162.

Boerner, R. E. J., J. Huang, and S. C. Hart (2008), Impacts of fire and fire surrogate treatments on ecosystem nitrogen storage patterns: Similarities and differences between forests of eastern and western North America, Can. J. For. Res., 38, 3056-3070, doi:10.1139/X08-144.

Bohrer, G., G. G. Katul, R. L. Walko, and R. Avissar (2009), Exploring the effects of microscale structural heterogeneity of forest canopies using 
large-eddy simulations, Boundary Layer Meteorol., 132, 351-382, doi:10.1007/s10546-009-9404-4.

Bormann, F. H., and G. E. Likens (1979), Catastrophic disturbance and the steady-state in northern hardwood forests, Am. Sci., 67, 660-669.

Burns, R. M., and B. H. Honkala (Eds.) (1990), Silvics of North America: 1. Conifers; 2. Hardwoods, U.S. Dept. Agric., Forest Service, Washington, D.C.

Caspersen, J. P., S. W. Pacala, J. C. Jenkins, G. C. Hurtt, P. R. Moorcroft, and R. A. Birdsey (2000), Contributions of land-use history to carbon accumulation in U.S. forests, Science, 290, 1148-1151, doi:10.1126/ science.290.5494.1148

Chen, B. Z., T. A. Black, N. C. Coops, T. Hilker, J. A. Trofymow, and K. Morgenstern (2009), Assessing tower flux footprint climatology and scaling between remotely sensed and eddy covariance measurements, Boundary Layer Meteorol., 130, 137-167, doi:10.1007/s10546-008-9339-1.

Chertov, O., J. S. Bhatti, A. Komarov, A. Mikhailov, and S. Bykhovets (2009), Influence of climate change, fire and harvest on the carbon dynamics of black spruce in Central Canada, For. Ecol. Manage., 257, 941-950, doi:10.1016/j.foreco.2008.10.038

Clark, K. L., N. Skowronski, and J. Hom (2010), Invasive insects impact forest carbon dynamics, Global Change Biol., 16, 88-101, doi:10.1111/ j.1365-2486.2009.01983.x.

Craine, J. M., et al. (2009), Global patterns of foliar nitrogen isotopes and their relationships with climate, mycorrhizal fungi, foliar nutrient concentrations, and nitrogen availability, New Phytol., 183, 980-992, doi:10.1111/j.1469-8137.2009.02917.x.

Curtis, P. S., C. S. Vogel, X. Z. Wang, K. S. Pregitzer, D. R. Zak, J. Lussenhop, M. Kubiske, and J. A. Teeri (2000), Gas exchange, leaf nitrogen, and growth efficiency of Populus tremuloides in a $\mathrm{CO}_{2}$ enriched atmosphere, Ecol. Appl., 10, 3-17.

Curtis, P. S., C. S. Vogel, C. M. Gough, H. P. Schmid, H.-B. Su, and B. D Bovard (2005), Respiratory carbon losses and the carbon-use efficiency of a northern hardwood forest, 1999-2003, New Phytol., 167, 437-456, doi:10.1111/j.1469-8137.2005.01438.x.

Davidson, E. A., P. A. Matson, P. M. Vitousek, R. Riley, K. Dunkin, G. Garcia-Mendez, and J. M. Maass (1993), Processes regulating soil emissions of $\mathrm{NO}$ and $\mathrm{N}_{2} \mathrm{O}$ in a seasonally dry tropical forest, Ecology, 74, 130-139, doi:10.2307/1939508.

Davis, M. B. (1989), Lags in vegetation response to greenhouse warming, Clim. Change, 15, 75-82, doi:10.1007/BF00138846.

Davis, M. R., R. B. Allen, and P. W. Clinton (2003), Carbon storage along a stand development sequence in a New Zealand Nothofagus forest, For. Ecol. Manage., 177, 313-321, doi:10.1016/S0378-1127(02)00333-X.

Detto, M., and G. G. Katul (2007), Simplified expressions for adjusting higher-order turbulent statistics obtained from open path gas analyzers, Boundary Layer Meteorol., 122, 205-216, doi:10.1007/s10546-0069105-1.

Detto, M., N. Montaldo, J. D. Albertson, and G. Katul (2006), Soil moisture and vegetation controls on evapotranspiration in a heterogeneous Mediterranean ecosystem on Sardinia, Italy, Water Resour. Res., 42 , W08419, doi:10.1029/2005WR004693.

Dore, S., T. E. Kolb, M. Montes-Helu, S. E. Eckert, B. W. Sullivan, B. A Hungate, J. P. Kaye, S. C. Hart, G. W. Koch, and A. Finkral (2010), Carbon and water fluxes from ponderosa pine forests disturbed by wildfire and thinning, Ecol. Appl., 20, 663-683, doi:10.1890/09-0934.1.

Duursma, R. A., and A. Makela (2007), Summary models for light interception and light-use efficiency of non-homogeneous canopies, Tree Physiol., 27, 859-870.

Foster, D. R., D. Aber, J. M. Melillo, R. D. Bowden, and F. A. Bazzaz (1997), Forest response to disturbance and anthropogenic stress, BioScience, 47, 437-445, doi:10.2307/1313059.

Frelich, L. E., and P. B. Reich (1995), Spatial patterns and succession in a Minnesota southern-boreal forest, Ecol. Monogr., 65, 325-346, doi: $10.2307 / 2937063$

Frey, B., F. Hagedorn, and F. Giudici (2006), Effect of girdling on soil respiration and root composition in a sweet chestnut forest, For. Ecol. Manage., 225, 271-277, doi:10.1016/j.foreco.2006.01.003.

Goodale, C. L., and J. D. Aber (2001), The long-term effects of land-use history on nitrogen cycling in northern hardwood forests, Ecol. Appl., 11, 253-267, doi:10.1890/1051-0761(2001)011[0253:TLTEOL]2.0. $\mathrm{CO} ; 2$.

Gough, C. M., C. S. Vogel, K. H. Harrold, K. George, and P. S. Curtis (2007), The legacy of harvest and fire on ecosystem carbon storage in a north temperate forest, Global Change Biol., 13, 1935-1949, doi:10.1111/j.1365-2486.2007.01406.x.

Gough, C. M., C. S. Vogel, H. P. Schmid, H.-B. Su, and P. S. Curtis (2008), Multi-year convergence of biometric and meteorological estimates of forest carbon storage, Agric. For. Meteorol., 148, 158-170, doi:10.1016/j.agrformet.2007.08.004
Gough, C. M., C. E. Flower, C. S. Vogel, D. Dragoni, and P. S. Curtis (2009), Whole-ecosystem labile carbon production in a north temperate deciduous forest, Agric. For. Meteorol., 149, 1531-1540, doi:10.1016/ j.agrformet.2009.04.006.

Gough, C. M., C. S. Vogel, B. Hardiman, and P. S. Curtis (2010), Wood net primary production resilience in an unmanaged forest transitioning from early to middle succession, For. Ecol. Manage., 260, 36-41, doi:10.1016/j.foreco.2010.03.027.

Gundersen, P., I. K. Schmidt, and K. Raulund-Rasmussen (2006), Leaching of nitrate from temperate forests-Effects of air pollution and forest management, Environ. Rev., 14, 1-57, doi:10.1139/a05-015.

Hall, S. J., P. A. Matson, and P. M. Roth (1996), NOx emissions from soil: Implications for air quality modeling in agricultural regions, Annu. Rev. Energy Environ., 21, 311-346, doi:10.1146/annurev.energy.21.1.311.

Hancock, J. E., M. A. Arthur, K. C. Weathers, and G. M. Lovett (2008), Carbon cycling along a gradient of beech bark disease impact in the Catskill Mountains, New York, Can. J. For. Res. 38, 1267-1274, doi:10.1139/X07-228.

Hardiman, B., G. Bohrer, C. M. Gough, C. S. Vogel, and P. S. Curtis (2011), The role of canopy structural complexity in wood net primary production of a maturing northern deciduous forest, Ecology, 92 , 1818-1827, doi:10.1890/10-2192.1.

Hendrick, R. L., and K. S. Pregitzer (1993), The dynamics of fine root length, biomass, and nitrogen content in two northern hardwood ecosystems, Can. J. For. Res. 23, 2507-2520, doi:10.1139/x93-312.

Hill, S. B., A. U. Mallik, and H. Y. H Chen (2005), Canopy gap disturbance and succession in trembling aspen dominated boreal forests in northeastern Ontario, Can. J. For. Res., 35, 1942-1951, doi:10.1139/ x05-126.

Hobbie, S. E. (2005), Contrasting effects of substrate and fertilizer nitrogen on the early stages of litter decomposition, Ecosystems, 8, 644-656, doi:10.1007/s10021-003-0110-7.

Högberg, P. (1990), Forests losing large quantities of nitrogen have elevated ${ }^{15} \mathrm{~N}:{ }^{14} \mathrm{~N}$ ratios, Oecologia, 84, 229-231.

Högberg, P., A. Nordgren, N. Buchmann, A. F. S. Taylor, A. Ekblad, M. N. Högberg, G. Nyberg, M. Ottosson-Löfvenius, and D. J. Read (2001) Large-scale forest girdling shows that current photosynthesis drives soil respiration, Nature, 411, 789-792, doi:10.1038/35081058.

Hollinger, D. Y., and A. D. Richardson (2005), Uncertainty in eddy covariance measurements and its application to physiological models, Tree Physiol., 25, 873-885.

Holmes, W. E., and D. R. Zak (1999), Soil microbial control of nitrogen loss following clearcut harvest in northern hardwood ecosystems, Ecol. Appl., 9, 202-215, doi:10.1890/1051-0761(1999)009[0202:SMCONL] 2.0.CO;2.

Houle, D., L. Duchesne, and R. Boutin (2009), Effects of a spruce budworm outbreak on element export below the rooting zone: A case study for a balsam fir forest, Ann. For. Sci., 66, 707, doi:10.1051/forest/ 2009057

Hsieh, C. I., M. Siqueira, G. Katul, and C.-R. Chu (2003), Predicting scalar source-sink and flux distributions within a forest canopy using a 2-D Lagrangian stochastic dispersion model, Boundary Layer Meteorol. 109, 113-138, doi:10.1023/A:1025461906331.

Ishii, H. T., S. Tanabe, and T. Hiura (2004), Exploring the relationships among canopy structure, stand productivity, and biodiversity of temperature forest ecosystems, For. Sci., 50(3), 342-355.

Jandl, R., M. Lindner, L. Vesterdal, B. Bauwens, R. Baritz, F. Hagedorn, D. W. Johnson, K. Minkkinen, and K. A. Byrne (2007), How strongly can forest management influence carbon sequestration?, Geoderma, 137, 253-268, doi:10.1016/j.geoderma.2006.09.003.

Johnson, D. W., and N. T. Edwards (1979), Effects of stem girdling on biogeochemical cycles within a mixed deciduous forest in eastern Tennessee. 2. Soil-nitrogen mineralization and nitrification rates, Oecologia, 40, 259-271, doi:10.1007/BF00345323.

Johnson, M. G., D. T. Tingey, D. L. Phillips, and M. J. Storm (2001), Advancing fine root research with minirhizotrons, Environ. Exp. Bot. 45, 263-289, doi:10.1016/S0098-8472(01)00077-6.

Jones, M. G. K., W. H. Outlaw, and O. H. Lowry (1977), Enzymic assay of $10^{-7}$ to $10^{-14}$ moles of sucrose in plant-tissues, Plant Physiol., 60 379-383, doi:10.1104/pp.60.3.379.

Kashian, D. M., W. H. Romme, D. B. Tinker, M. G. Turner, and M. G. Ryan (2006), Carbon storage on landscapes with stand-replacing fires, BioScience, 56, 598-606, doi:10.1641/0006-3568(2006)56[598: CSOLWS]2.0.CO;2.

Kaye, J. P., S. C. Hart, P. Z. Fulé, W. W. Covington, M. M. Moore, and M. W. Kaye (2005), Initial carbon, nitrogen, and phosphorus fluxes following ponderosa pine restoration treatments, Ecol. Appl., 15, 1581-1593, doi:10.1890/04-0868. 
Kinney, K. K., R. L. Lindroth, S. M. Jung, and E. V. Nordheim, (1997), Effects of $\mathrm{CO}_{2}$ and $\mathrm{NO}_{3}^{-}$availability on deciduous trees: Phytochemistry and insect performance, Ecology, 78, 215-230.

Kneeshaw, D. D., and Y. Bergeron (1998), Canopy gap characteristics and tree replacement in the southeastern boreal forest, Ecology, 79, 783-794, doi:10.1890/0012-9658(1998)079[0783:CGCATR]2.0.CO;2.

Knohl, A., O. Kolle, T. Y. Minayeva, I. M. Milyukova, N. N. Vygodskaya, T. Foken, and E.-D. Schulze (2002), Carbon dioxide exchange of a Russian boreal forest after disturbance by wind throw, Global Change Biol., 8, 231-246, doi:10.1046/j.1365-2486.2002.00475.x.

Law, B. E., P. E. Thornton, J. Irvine, P. M. Anthoni, and S. Van Tuyl (2001), Carbon storage and fluxes in ponderosa pine forests at different developmental stages, Global Change Biol., 7, 755-777, doi:10.1046/ j.1354-1013.2001.00439.x.

LeDuc, S. D., and D. E. Rothstein (2007), Initial recovery of soil carbon and nitrogen pools and dynamics following disturbance in jack pine forests: A comparison of wildfire and clearcut harvesting, Soil Biol. Biochem., 39, 2865-2876, doi:10.1016/j.soilbio.2007.05.029.

Likens, G. E., F. H. Bormann, N. M. Johnson, D. W. Fisher, and R. S. Pierce (1970), Effects of forest cutting and herbicide treatment on nutrient budgets in Hubbard Brook Watershed-Ecosystem, Ecol. Monogr. 40, 23-47, doi:10.2307/1942440.

Lindahl, B. D., W. de Boer, and R. D. Finlay (2010), Disruption of root carbon transport into forest humus stimulates fungal opportunists at the expense of mycorrhizal fungi, ISME J., 4, 872-881, doi:10.1038/ ismej.2010.19.

Lindroth, A., F. Lagergren, A. Grelle, L. Klemedtsson, O. Langvall, P. Weslien, and J. Tuulik (2009), Storms can cause Europe-wide reduction in forest carbon sink, Global Change Biol., 15, 346-355, doi:10.1111/ j.1365-2486.2008.01719.x.

Luyssaert, S., E.-D. Schulze, A. Börner, A. Knohl, D. Hessenmöller, B. E. Law, P. Ciais, and J. Grace (2008), Old-growth forests as global carbon sinks, Nature, 455, 213-215, doi:10.1038/nature07276.

Magnani, F., et al. (2007), The human footprint in the carbon cycle of temperate and boreal forests, Nature, 447, 849-851, doi:10.1038/ nature 05847

Martin, J. L., S. Gower, J. Plaut, and B. Holmes (2005), Carbon pools in a boreal mixed wood logging chronosequence, Global Change Biol., 11, 1883-1894, doi:10.1111/j.1365-2486.2005.01019.x.

Martin, T. A., and E. J. Jokela (2004), Developmental patterns and nutrition impact radiation use efficiency components in southern pine stands, Ecol. Appl., 14, 1839-1854, doi:10.1890/03-5262.

McCalley, C. K., and J. P. Sparks (2008), Controls over nitric oxide and ammonia emissions from Mojave Desert soils, Oecologia, 156, 871-881, doi:10.1007/s00442-008-1031-0.

McDowell, W. H., A. H. Magill, J. A. Aitkenhead-Peterson, J. D. Aber, J. L. Merriam, and S. S. Kaushal (2004), Effects of chronic nitrogen amendment on dissolved organic matter and inorganic nitrogen in soil solution, For. Ecol. Manage., 196, 29-41, doi:10.1016/j.foreco.2004.03.010.

Misson, L., J. Tang, M. Xu, M. McKay, and A. Goldstein (2005), Influences of recovery from clear-cut, climate variability, and thinning on the carbon balance of a young ponderosa pine plantation, Agric. For. Meteorol., 130, 207-222, doi:10.1016/j.agrformet.2005.04.001.

Nadelhoffer, K. J., J. D. Aber, and J. M. Melillo (1985), Fine roots, net primary production, and soil-nitrogen availability: A new hypothesis, Ecology, 66, 1377-1390, doi:10.2307/1939190.

Nave, L. E., C. S. Vogel, C. M. Gough, and P. S. Curtis (2009), Contribution of atmospheric nitrogen deposition to net primary productivity in a northern hardwood forest, Can. J. For. Res., 39, 1108-1118, doi:10.1139/X09-038.

Nilsson, L. O., H. Wallander, E. Bååth, and U. Falkengren-Grerup (2006), Soil $\mathrm{N}$ chemistry in oak forests along a nitrogen deposition gradient, Biogeochemistry, 80, 43-55, doi:10.1007/s10533-005-6220-x.

Nuckolls, A. E., N. Wurzburger, C. R. Ford, R. L. Hendrick, J. M. Vose, and B. D. Kloeppel (2009), Hemlock declines rapidly with hemlock woolly adelgid infestation: Impacts on the carbon cycle of southern Appalachian forests, Ecosystems N. Y, 12, 179-190, doi:10.1007/ s10021-008-9215-3.

Overpeck, J. T., D. Rind, and R. Goldberg (1990), Climate-induced changes in forest disturbance and vegetation, Nature, 343, 51-53, doi:10.1038/343051a0.

Palik, B. J., and K. S. Pregitzer (1993), The vertical development of early successional forests in northern Michigan, USA, J. Ecol., 81, 271-285, doi:10.2307/2261497.

Papale, D., and A. Valentini (2003), A new assessment of European forests carbon exchanges by eddy fluxes and artificial neural network spatialization, Global Change Biol., 9, 525-535, doi:10.1046/j.13652486.2003.00609.x.
Papale, D., et al. (2006), Towards a standardized processing of Net Ecosystem Exchange measured with eddy covariance technique: Algorithms and uncertainty estimation, Biogeosciences, 3, 571-583, doi:10.5194/bg-3$571-2006$

Pardo, L. H., H. F. Hemond, J. P. Montoya, T. J. Fahey, and T. G. Siccama (2002), Response of the natural abundance of ${ }^{15} \mathrm{~N}$ in forest soils and foliage to high nitrate loss following clear-cutting, Can. J. For. Res., 32, 1126-1136, doi:10.1139/x02-041.

Paul, K. I., P. J. Polglase, J. G. Nyakuengama, and P. K. Khanna (2002), Change in soil carbon following afforestation, For. Ecol. Manage., 168, 241-257, doi:10.1016/S0378-1127(01)00740-X

Pregitzer, K. S., and E. S. Euskirchen (2004), Carbon cycling and storage in world forests: Biome patterns related to forest age, Global Change Biol., 10, 2052-2077, doi:10.1111/j.1365-2486.2004.00866.x.

Reich, P. B., D. W. Peterson, D. A. Wedin, and K. Wrage (2001), Fire and vegetation effects on productivity and nitrogen cycling across a forestgrassland continuum, Ecology, 82, 1703-1719, doi:10.1890/0012-9658 (2001)082[1703:FAVEOP]2.0.CO;2.

Reichstein, M., et al. (2005), On the separation of net ecosystem exchange into assimilation and ecosystem respiration: Review and improved algorithm, Global Change Biol., 11, 1424-1439, doi:10.1111/j.13652486.2005.001002.x

Russow, R., O. Spott, and C. F. Stange (2008), Evaluation of nitrate and ammonium as sources of $\mathrm{NO}$ and $\mathrm{N}_{2} \mathrm{O}$ emissions from black earth soils [Haplic Chernozem] based on ${ }^{15} \mathrm{~N}$ field experiments, Soil Biol. Biochem., 40, 380-391, doi:10.1016/j.soilbio.2007.08.020.

Scharenbroch, B. C., and J. G. Bockheim (2008), The effects of gap disturbance on nitrogen cycling and retention in late-successional northern hardwood-hemlock forests, Biogeochemistry, 87, 231-245, doi:10.1007/s10533-008-9180-0.

Schmid, H. P., H.-B. Su, C. S. Vogel, and P. S. Curtis (2003), Ecosystematmosphere exchange of carbon dioxide over a mixed hardwood forest in northern lower Michigan, J. Geophys. Res., 108(D14), 4417, doi:10.1029/2002JD003011.

Scott-Denton, L. E., T. N. Rosenstiel, and R. K. Monson (2006), Differential controls by climate and substrate over the heterotrophic and rhizospheric components of soil respiration, Global Change Biol., 12, 205-216, doi:10.1111/j.1365-2486.2005.01064.x

Smaill, S. J., P. W. Clinton, and R. B. Allen (2009), Inter-specific variation in foliar nutritional responses to disturbance by small coupe harvesting varies with landscape position, For. Ecol. Manage., 258, 2382-2387, doi:10.1016/j.foreco.2009.08.014

Sparks, J. P., and J. R. Ehleringer (1997), Leaf carbon isotope discrimination and nitrogen content for riparian trees along elevational transects, Oecologia, 109, 362-367, doi:10.1007/s004420050094.

Sprugel, D. G. (1984), Density, biomass, productivity, and nutrient-cycling changes during stand development in wave-regenerated balsam fir forests, Ecol. Monogr., 54, 165-186, doi:10.2307/1942660.

Stearns, F., and G. E. Likens (2002), One hundred years of recovery of a pine forest in northern Wisconsin, The Am. Midland Natural., 148, 2-19, doi:10.1674/0003-0031(2002)148[0002:OHYORO]2.0.CO;2.

Sullivan, B., T. E. Kolb, S. C. Hart, J. P. Kaye, S. Dore, and M. Montes-Helu (2008), Thinning reduces soil carbon dioxide but not methane flux from southwestern USA ponderosa pine forests, For. Ecol. Manage., 255, 4047-4055, doi:10.1016/j.foreco.2008.03.051.

Swank, W. T., J. M. Vose, and K. J. Elliott (2001), Long-term hydrologic and water quality responses following commercial clearcutting of mixed hardwoods on a southern Appalachian catchment, For. Ecol. Manage. 143, 163-178, doi:10.1016/S0378-1127(00)00515-6.

Thornton, P. E., et al. (2002), Modeling and measuring the effects of disturbance history and climate on carbon and water budgets in evergreen needleleaf forests, Agric. For. Meteorol., 113, 185-222, doi:10.1016/ S0168-1923(02)00108-9.

Tian, D.-L., W.-D. Yan, W.-X. Kang, X.-W. Deng, and G.-J. Wang (2009), Influence of thinning on soil $\mathrm{CO}_{2}$ efflux in Chinese fir plantations, Pedosphere, 19, 273-280, doi:10.1016/S1002-0160(09)60118-1.

Vitousek, P. M., and R. W. Howarth (1991), Nitrogen limitation on land and in the sea - How can it occur?, Biogeochemistry, 13, 87-115, doi:10.1007/BF00002772.

Webb, T., and P. J. Bartlein (1992), Global changes during the last 3 million years: Climatic controls and biotic responses, Annu. Rev. Ecol. Syst., 23, 141-173, doi:10.1146/annurev.es.23.110192.001041.

Westbrook, C. J., and K. J. Devito (2004), Gross nitrogen transformations in soils from uncut and cut boreal upland and peatland coniferous fores stands, Biogeochemistry, 68, 33-50, doi:10.1023/B:BIOG.0000025739. 04821.8e.

Wirth, C., E.-D. Schulze, B. Lühker, S. Grigoriev, M. Siry, G. Hardes, W. Ziegler, M. Backor, G. Bauer, and N. N. Vygodskaya (2002), Fire and site type effects on the long-term carbon and nitrogen balance in 
pristine Siberian Scots pine forests, Plant Soil, 242, 41-63, doi:10.1023 A:1020813505203.

Wolter, P. T., and M. A. White (2002), Recent forest cover type transitions and landscape structural changes in northeast Minnesota, USA, Landscape Ecol., 17, 133-155, doi:10.1023/A:1016522509857.

Zak, D. R., G. E. Host, and K. S. Pregitzer (1989), Regional variability in nitrogen mineralization, nitrification, and overstory biomass in northern Lower Michigan, Can. J. For. Res., 19, 1521-1526, doi:10.1139/x89231 .

Zeller, B., J. Liu, N. Buchmann, and A. Richter (2008), Tree girdling increases soil N mineralisation in two spruce stands, Soil Biol. Biochem. 40, 1155-1166, doi:10.1016/j.soilbio.2007.12.009

Zwieniecki, M. A., L. Hutyra, M. V. Thompson, and N. M. Holbrook (2000), Dynamic changes in petiole specific conductivity in red maple (Acer rubrum L.), tulip tree (Liriodendron tulipifera L.) and northern fox grape, (Vitis labrusca L.), Plant Cell Environ., 23, 407-414, doi:10.1046/j.1365-3040.2000.00554.X

Zwieniecki, M. A., P. J. Melcher, T. S. Field, and N. M. Holbrook (2004) A potential role for xylem-phloem interactions in the hydraulic architec- ture of trees: Effects of phloem girdling on xylem hydraulic conductance, Tree Physiol., 24, 911-917, doi:10.1093/treephys/24.8.911.

G. Bohrer and K. D. Maurer, Department of Civil and Environmental Engineering and Geodetic Science, Ohio State University, Columbus, $\mathrm{OH} 43210$, USA

P. S. Curtis and B. S. Hardiman, Department of Evolution, Ecology, and Organismal Biology, Ohio State University, Columbus, OH 43210, USA

C. M. Gough, Department of Biology, Virginia Commonwealth University, Richmond, VA 23284, USA.

J. Le Moine, K. J. Nadelhoffer, L. E. Nave, and C. S. Vogel, University of Michigan Biological Station, Pellston, MI 49769, USA.

A. B. Munoz, Columbia University, New York, NY 10027, USA

J. P. Sparks, Department of Ecology and Evolutionary Biology, Cornell University, Ithaca, NY 14850, USA.

B. D. Strahm, Department of Forest Resources and Environmental Conservation, Virginia Polytechnic Institute and State University, Blacksburg, VA 24061, USA. 